\title{
How does the IASB Use the Conceptual Framework in Developing IFRSs? An Examination of the Development of IFRS 16 Leases
}

\section{Citation}

Kabir, H. and Rahman, A. (Forthcoming). How does the IASB Use the Conceptual Framework in Developing IFRSs? An Examination of the Development of IFRS 16 Leases. Journal of Financial Reporting, 3(1), 93-116. https://doi.org/10.2308/jfir-52232

\author{
Humayun Kabir* \\ Auckland University of Technology \\ Auckland, New Zealand \\ E-mail: humayun.kabir@aut.ac.nz \\ Asheq Rahman \\ Auckland University of Technology \\ Auckland, New Zealand \\ E-mail: asheq.rahman@aut.ac.nz
}

Running head: How does the IASB Use the Conceptual Framework?

${ }^{*}$ Corresponding author

We are grateful to the editor and two anonymous reviewers for their helpful comments on earlier versions of this paper. 


\title{
How does the IASB Use the Conceptual Framework in Developing IFRSs? An Examination of the Development of IFRS 16 Leases
}

\begin{abstract}
We examine how the International Accounting Standards Board (IASB) used the Conceptual Framework for Financial Reporting (Framework) in developing the new lease accounting standard International Financial Reporting Standard (IFRS) 16 Leases. We report three major findings in this paper. First, while the IASB used the Framework concepts to justify new lease accounting requirements, it also used an outside-the-Framework notion to justify a requirement. Second, accommodating constituents' demands, it introduced rules in IFRS 16 to mitigate their concerns relating to high implementation costs. Third, there are instances where the IASB did not apply appropriate concepts to justify lease accounting requirements. These findings have implications for setting IFRSs.
\end{abstract}

Keywords: conceptual framework; accounting standard setting; accounting for leases; IFRS; principles-based standards; rules-based standards

JEL Classifications: D71, D72, M41 


\section{INTRODUCTION}

In this study, we examine how the International Accounting Standards Board (IASB) used the Conceptual Framework for Financial Reporting (Framework) in developing IFRS 16 Leases. The IASB used considerable resources in updating the Framework. ${ }^{1}$ In 2004, the IASB and the Financial Accounting Standards Board (FASB) initiated a joint project to revise their conceptual frameworks (IASB 2013k). The IASB issued a discussion paper (DP) outlining its preliminary views on two chapters ${ }^{2}$ of an improved conceptual framework in 2006, released an exposure draft (ED) of these two chapters in 2008, and finalised the chapters in 2010 (IASB 2006b, 2008, 2013k). It released a DP entitled "A Review of the Conceptual Framework for Financial Reporting" in 2013 and an ED of the revised conceptual framework in $2015,{ }^{3}$ and finally issued the updated Framework in March 2018 (IASB 2013k, 2015, 2018).

What motivated the expenditure of a significant amount of resources in updating the Framework is its role in setting International Financial Reporting Standards (IFRSs). The Framework is a set of concepts that underlie the preparation and presentation of general-purpose financial statements (IASB 2010c). The primary purpose of the Framework is to help the IASB develop new IFRSs and revise existing IFRSs (IASB 2010c). ${ }^{4}$ Because of this, both the IASB and its constituents place great

\footnotetext{
1 The International Accounting Standards Committee (IASC), the IASB's predecessor body, came into existence in 1973, and issued its first framework in 1989 (IASB 2015, 6).

${ }^{2}$ The chapters are Chapter 1, The Objective of Financial Reporting, and Chapter 2, Qualitative Characteristics of Decision-useful Financial Reporting Information (IASB 2006b).

3 The United States (U.S.) has a long history of devoting significant resources to the development of a conceptual framework. The earliest institutional attempts at developing a framework include Moonitz (1961), Sprouse and Moonitz (1962), A Statement of Basic Accounting Theory (Committee to Prepare a Statement of Basic Accounting Theory 1966), Accounting Principles Board Statement No. 4 (APB 1970), the Trueblood Report (Study Group on the Objectives of Financial Statements 1973), and the FASB Concepts Statements.

4 The FASB (2017) expresses the role of its Conceptual Framework more emphatically: "The FASB is the most direct beneficiary of the framework. The framework provides the FASB with a foundation for setting standards and concepts to use as tools for resolving accounting and reporting questions."
} 
emphasis on the Framework. This is manifested in the feedback constituents gave on the urgency of revising the Framework in response to the IASB Agenda Consultation of 2011 (IASB 2012).

However, accounting standard setting is also a political process (André, CazavanJeny, Dick, Richard, and Walton 2009; Beresford 1988, 2001; Zeff 2002). On one hand, the IASB's constituents want to influence the standard-setting outcome (André et al. 2009; Pelger and Spiess 2017). On the other hand, being a private sector standard setter, the IASB must rely on the support of national jurisdictions and regulators, and has incentives to act to enhance its legitimacy as a rule-making body (Camfferman and Zeff 2018; Pelger and Spiess 2017). Therefore, notwithstanding the importance attached to the Framework, the role of the Framework in setting IFRSs is unclear in this political setting. While a number of studies have examined the IASB's due process and political interventions by constituents in setting IFRSs (André et al. 2009; Cortese and Irvine 2010; Cortese, Irvine, and Kaidonis 2010; Giner and Arce 2012; Jorissen, Lybaert, Orens, and van der Tas 2012, 2013; Mellado and Parte 2017; Pelger and Spiess 2017), we are not aware of any empirical study that examines how the IASB has applied the Framework in developing IFRSs. ${ }^{5}$ This is notwithstanding the fact that accounting standards setting is a technical exercise in a political environment.

To fill this gap in the standard-setting literature, we investigate how the IASB applied the Framework in developing IFRS $16 .{ }^{6}$ More specifically, we focus on three research questions (RQs) germane to standard setting based on the Framework. First,

\footnotetext{
${ }^{5}$ Several papers focused on the conceptual analyses of the conceptual framework (Abela, Barker, Sommer, Teixeira, and André 2014; Barker 2015; Bauer, O'Brien, and Saeed 2014; Brouwer, Faramarzi, and Hoogendoorn 2014; Brouwer, Hoogendoorn, and Naarding 2015; Christensen 2010; Gebhardt, Mora, and Wagenhofer 2014; Macve 2010; Nobes and Stadler 2015; van Mourik 2014; Zeff 2013).

${ }^{6}$ We draw on the 2010 version of the Framework in this paper because this is the version that was available to the IASB when it developed the DP, EDs and IFRS 16.
} 
what Framework concepts and outside-the-Framework notions, if any, did the IASB use in justifying IFRS 16 lease accounting requirements? Second, what rules, if any, did the IASB incorporate in IFRS 16 and why? Third, how did the IASB apply the concepts in developing IFRS 16 requirements?

There are two reasons why we selected IFRS 16 as a case. First, IFRS 16 was issued very recently. Therefore, examining the role of the Framework in the development of IFRS 16 should reveal how the IASB used the Framework in relation to IFRS 16 during the years 2009-16. Second, after the publication of a DP in 2009, it took the IASB about seven years to issue the final standard, IFRS $16 .{ }^{7}$ Constituents' serious disagreements with certain aspects of the proposed lease accounting project and the IASB's addressing of those concerns caused this delay. Therefore, the development of IFRS 16 provides an interesting setting for examining how the IASB uses the Framework in the process of developing IFRSs.

Although we investigate IFRS 16 , our paper is of potential interest to the FASB and its constituents. This is because the FASB and the IASB have similar conceptual frameworks, and accounting for leases was a joint project of these two boards, so that IFRS 16 and FASB Topic 842 Leases are significantly converged ${ }^{8}$ (FASB 2016). Further, both the U.S. Securities and Exchange Commission (SEC) and the FASB deliberated the

\footnotetext{
7 The IASB issued a DP in 2009 (DP2009), followed by two EDs - the first in August 2010 (ED2010) and the second in May 2013 (ED2013), before issuing the final standard IFRS 16 in 2016.
}

8 Like IFRS 16, FASB Topic 842 requires the lessee to recognise a right-of-use asset and a lease liability for all leases, except for short-term leases (FASB 2016, 3). The main differences relate to the recognition of lease expense for operating leases and the accounting for leases of low-value assets. Unlike IFRS 16, which requires the separate recognition of interest expense on the lease liability and the amortization of the right-of-use asset for all leases, FASB Topic 842 requires the lessee to recognise a single lease expense for operating leases on a straight-line basis (FASB 2016, 3). Further, while IFRS 16 allows recognition exemption for low-value leases, FASB Topic 842 provides no such exemption (FASB 2016, 7-8). For differences between IFRS 16 and FASB Topic 842, see FASB (2016, 7-9). 
development of objectives-oriented accounting standards (FASB 2002, 2004; SEC 2003). Finally, the U.S. has significant stakes in how IFRSs are set. ${ }^{9}$

Our paper is also important from another perspective. While U.S. GAAP has been alleged to be rules-based, IFRSs have been regarded as principles-based ${ }^{10}$ (Bhimani 2008; Nobes 2005). However, compared with U.S. GAAP which has been applied in the U.S. for many years, IFRSs became mandatory and started affecting reporting entities across the world only recently. ${ }^{11}$ Thus, constituents' interests in how IFRSs are set and their consequent involvement in the IFRS setting process are likely to increase with mandatory adoption. The pressures from European constituents in forcing the IASB to amend International Accounting Standard (IAS) 39, allowing reclassification of financial instruments, support this (André et al. 2009). In this context also, it is important to see how far the IASB applied the Framework concepts in the face of constituents' intervention.

We conducted this study by analysing the due process documents - DP2009, ED2010, ED2013, IFRS 16, and the basis for conclusions that accompanied them as well as the constituents' comments on them and IASB/FASB Staff papers.

Regarding the first RQ, we find that the IASB referred to the overarching objective of decision-usefulness, the definitions of an asset and a liability, the fundamental qualitative characteristics of relevance and faithfulness representation, the enhancing quality of comparability and the related notion of consistency, and the cost constraint to justify lease accounting requirements. We also observe that the IASB

\footnotetext{
9This is reflected in the significant involvement of the U.S. in the Monitoring Board, the IFRS Foundation and the IASB (IFRS Foundation 2016b), and the SEC's acceptance of IFRS financial statements without reconciliation from foreign private issuers (SEC 2007).

10 Although FASB standards contain rules, Schipper (2003) argues and demonstrates that the rules are based on concepts. Further, Nelson (2003) argues that all accounting standards can be viewed as principles-based although they include varying amounts of rules.

${ }^{11}$ While some European companies adopted IFRSs voluntarily before they became mandatory in 2005, the number of voluntary adopters was small (Cuijpers and Buijink 2005).
} 
drew on a notion from outside the Framework to justify the initial recognition and measurement date for the right-of-use asset and the lease liability.

Regarding the second RQ, we observe that the IASB started with principlesbased accounting requirements and initially limited the extent of application guidance. However, considering constituents' demands and the cost constraint, the IASB incorporated recognition exemptions and qualitative thresholds, and expanded the application guidance in IFRS 16 . We also find the IASB very prescriptive in specifying detailed accounting requirements for certain lease accounting issues, which could be addressed by developing a general principle.

With respect to the third RQ, we find that while the IASB drew on the definitions of an asset and a liability to specify the accounting requirement for the right-of-use asset and the lease liability, it deviated from the liability definition when specifying the requirement for the lease term option. We also observe that the IASB invoked the notion of consistency rather than the fundamental qualitative characteristic of relevance to justify the initial measurement basis for the right-of-use asset. Nor did the IASB rely on relevance and faithful representation to specify the initial measurement of the lease liability.

Our paper makes three contributions to the accounting standards-setting literature. First, our findings enhance our understanding of how the IASB uses the Framework in developing IFRSs. Prior empirical studies primarily focus on political interventions by IASB constituents in setting IFRSs (André et al. 2009; Bamber and McMeeking 2016; Cortese and Irvine 2010; Cortese et al. 2010; Giner and Arce 2012; Jorissen et al. 2012, 2013; Mellado and Parte 2017; Pelger and Spiess 2017). However, accounting standards setting is a complex process, requiring a consideration of both conceptual and political issues. We demonstrate how the IASB considered both the Framework and constituents' feedback in setting IFRS 16. 
Second, the literature on rules-based vs. principles-based accounting standards primarily focuses on their pros and cons (AAAFASC 2003; FASB 2002; Imhoff Jr and Thomas 1988; Lys and Vincent 1995; Nelson 2003; Nelson, Elliott, and Tarpley 2002; Nobes 2005; Schipper 2003; SEC 2003). Very few empirical studies examine why rules emerge in IFRSs. Schipper (2003) and AAAFASC (2003) suggest that rules are incorporated in U.S. standards to mitigate the concerns of constituents. Nobes (2005) argues that rules emerge because of the failure to use appropriate principles. We add to these studies by providing evidence on why the IASB incorporated rules in IFRS 16.

Third, prior studies report uneven participation and potentially undue influences of different constituent groups in IASB due process (Cortese and Irvine 2010; Cortese et al. 2010; Jorissen et al. 2012, 2013; Mellado and Parte 2017), raising concerns about the potential for biased outcomes ${ }^{12}$. However, our findings suggest that the intensity of participation of certain constituent groups in due process is not necessarily translated into outcomes desired by these groups. For example, consistent with prior studies (Bamber and McMeeking 2016; Jorissen et al. 2012), we find that preparers submitted a far greater number of comment letters than users. However, despite many preparers' disagreements with the right-of-use model, the IASB adopted it in IFRS 16 based on the argument that the model provides useful information to users. To mitigate the preparers' concern over high implementation costs, the IASB incorporated, inter alia, recognition exemptions for short-term and low value leases.

We structure the remainder of this paper as follows. We briefly survey two standard setting debates in section 2, and describe the data, method and scope of the study in section 3 . In section 4 , we examine what concepts the IASB used to justify the accounting requirements in IFRS 16 . We examine whether the IASB incorporated rules in IFRS 16 in section 5, and investigate how the IASB applied the Framework concepts

12 This happens when, for example, certain constituent groups capture the due process. This is called the regulatory capture theory (Cortese et al. 2010). 
to derive IFRS 16 requirements in section 6. Finally, we discuss the implications, future research opportunities and limitations in section 7 .

\section{STANDARD-SETTING DEBATES}

Our study concerns two related streams of the accounting standard-setting literature. First, two contrasting perspectives on accounting standards setting have long dominated the accounting literature. The technical perspective argues that accounting is a purely technical "mapping" exercise (Solomons 1978). This perspective views the essential nature of accounting as "cartographic" (Solomons 1978, 70). On the other hand, the political perspective views accounting standards setting as a political process (Moonitz 1974; Zeff 1978, 2005), because it influences the behaviour of the constituents and has economic consequences. Therefore, the proponents of this perspective propose that the accounting standard setters should take the detrimental effects of accounting standards on preparers into account ${ }^{13}$ when setting accounting standards (Solomons 1978; Zeff 1978).

Different groups of constituents have conflicting preferences for accounting requirements, and the standard setter must balance these conflicting preferences to survive and achieve legitimacy for itself (Beresford 1988, 1993). ${ }^{14}$ Since IFRSs are used in many countries, the IASB is likely to face competing demands from a diverse group of constituents (André et al. 2009; Cortese et al. 2010; McGregor 2012). The IASB

\footnotetext{
${ }^{13}$ Apart from the political lobbying of IASB constituents we already noted, a sizeable literature also demonstrates political lobbying and interventions in setting accounting standards in the U.S. (Allen 2014; Francis 1987; Kelly 1985; Moonitz 1974; Puro 1984; Watts and Zimmerman 1978; Zeff 2002).

${ }^{14}$ André et al. (2009) demonstrate how pressures from European banks, the European Central Bank, former French President Jacques Chirac and the European Commission to allow reclassification of financial instruments under IAS 39 put the survival of the IASB in jeopardy and the IASB bowed to these pressures. In the U.S. the APB and the FASB bowed to political pressures on several occasions. Examples include political pressures applied on the APB and the FASB when setting accounting standards on investment tax credit in the 1960s and business combinations during 1999-2000, respectively (Beresford 2001; Moonitz 1974).
} 
recognises this political aspect of standard setting by following an elaborate due process as laid out in the IFRS Foundation's Due Process Handbook and seeking feedback from financial reporting constituents: users, preparers, auditors, national accounting standards setters, regulators and academics (IFRS Foundation 2016a).

Notwithstanding the political nature of accounting standards setting, many consider the use of a theoretical framework to be indispensable in this process (Gaa 1988; Moonitz 1974). However, the political nature of IFRS setting makes the role of the Framework in setting IFRSs uncertain. It is unclear how the IASB uses the Framework in navigating through this political process. Therefore, we investigate how the IASB used the Framework in developing IFRS 16.

Second, there has also been a debate on whether accounting standards should be rules-based or principles-based. ${ }^{15}$ Principles-based standards are based on a conceptual framework and contain fewer exceptions and less detailed implementation guidance (SEC 2003; Schipper 2003; Wells 2011). Conversely, rules-based standards contain bright line tests, exceptions and detailed implementation guidance (SEC 2003; Schipper 2003). Nobes (2005) suggests that the failure to use appropriate principles leads to a standard-setter's reliance on too many rules in accounting standards and argues that the use of appropriate principles would reduce that reliance on rules.

Many consider IFRSs to be principles-based (Nobes 2005). Therefore, it is important from the perspective of standard-setting transparency to see whether the IASB uses any notions from outside the Framework and whether it incorporates any rules in IFRSs. It is also important to examine whether the IASB follows the hierarchy of qualitative characteristics and the definitions of the elements of financial statements laid out in the Framework in developing IFRSs. To address these issues, we examine how the IASB applied the Framework in developing IFRS 16.

\footnotetext{
${ }^{15}$ Schipper (2003) provides an excellent exposition of this debate.
} 


\section{DATA, METHOD AND SCOPE}

We base our paper on an analysis of DP2009, ED2010 and ED2013, three IASB/FASB Staff papers summarising the constituents' feedback on these documents, IFRS 16, and the basis for conclusions in ED2010, ED2013 and IFRS 16. We also collected 302 comment letters on DP2009, 786 comment letters on ED2010 and 641 comment letters on ED2013 to see how the respondents responded to the questions addressed in this paper. The authors collected all these documents gradually over several years prior to 2016, as the documents were made available on the IASB website, ${ }^{16}$ and analysed the documents during 2016-17.

While the analyses and interpretations of these documents are ours, we provide pertinent quotations from due process documents and respondents' comment letters, and detailed citations of the paragraph numbers of due process documents (i.e., DP 2009, ED2010, ED2013, IFRS 16 and basis for conclusions) as well as the comment letter numbers to enhance the reliability of our results.

IFRS 16 represents a major change in the lessee accounting model. IAS 17 classified leases into two types - finance leases and operating leases ${ }^{17}$, and required the lessee to recognise a leased asset and a lease liability for finance leases only (IASB

16 The following website contains the due process documents (e.g., DP2009, ED2010, and ED2013) related to the development of IFRS 16 as well as links to related documents:

http://archive.ifrs.org/Current-Projects/IASB-Projects/Leases/Pages/Leases.aspx. As we were revising this paper, the IASB developed a new website. The documents related to IFRS 16 development were not transferred to the new website at the time of revising this paper. At the time of revising this paper, all comment letters on DP2009 were publicly available on: http://archive.ifrs.org/Current-Projects/IASB-Projects/Leases/DPMar09/Comment-

Letters/Pages/Comment-letters.aspx. The comment letters on ED2010 were available on: http://www.fasb.org/jsp/FASB/CommentLetter_C/CommentLetterPage\&cid=1218220137090\&pro ject_id=1850-100\&page_number=1. Finally, the comment letters on ED2013 were available on: http://www.fasb.org/jsp/FASB/CommentLetter_C/CommentLetterPage\&cid=1218220137090\&pro ject_id=2013-270\&page_number=1.

17 A finance lease is defined as "a lease that transfers substantially all the risks and rewards incidental to ownership of an asset" (IASB 2013e, para. 4). A lease other than a finance lease is an operating lease (IASB 2013e, para. 4). 
2013e, paras. 8 and 20). However, the lessee had to recognise the lease payment under an operating lease as an expense on a straight-line basis over the lease term (IASB 2013e, para. 33). In contrast, IFRS 16 requires the lessee to recognise a right-of-use asset and a lease liability for all leases, except for short-term leases and leases of lowvalue assets (IASB 2016b, paras. 5 and 22). Because lessor accounting under IFRS 16 remains substantially unchanged (IASB 2016b, para. IN14), in this study we focus on the accounting for leases by the lessee.

\section{THE FRAMEWORK CONCEPTS AND OUTSIDE-THE-FRAMEWORK NOTIONS}

Table 1 reports the lease accounting issues addressed by IFRS 16, the accounting requirement for each issue, and the concepts that the IASB mentioned as justifications for those requirements. We observe in Table 1 that, as expected, the IASB drew on the Framework concepts to justify lease accounting requirements. Concepts offered as justifications for lease accounting requirements include the overarching objective of decision-usefulness as well as the definitions of an asset and a liability, and the qualitative characteristics of accounting information. The qualitative characteristics used include the fundamental qualitative characteristics of relevance and faithful representation, the enhancing quality of comparability, and the cost constraint. We also see that the IASB used the notion of consistency with other IFRSs in justifying many lease accounting requirements.

\section{Table 1 about here}

We note in Table 1 that the IASB used a notion outside the Framework, along with the Framework concepts, to justify the initial recognition and measurement date of the right-of-use asset and the lease liability. IFRS 16 requires that the right-of-use asset 
and the lease liability be measured at the commencement date rather than at the inception date (IASB 2016b, paras. 22, 23 and 26). The arguments for this requirement are couched in terms of its consistency with the lease accounting model and the measurement date for other assets as well as the outside-the-Framework notion that the lessee should not recognise any gain or loss on the initial recognition of the asset and liability $^{18}$ (IASB 2016a, paras. BC142-BC144).

\section{RULES IN IFRS 16}

While the requirements in IFRS 16 are based on the Framework concepts, we observe that the IASB inserted some rules $^{19}$ in IFRS 16 . Consistent with the U.S. standard-setting literature (FASB 2002; Schipper 2003), these rules were the result of constituents' demands and the application of the cost constraint. Examples include the recognition exemptions allowed for short-term and low value leases, and the qualitative threshold "reasonably certain" for the recognition of lease term options (IASB 2016a, 2016b).

Further, in response to constituents' requests, the IASB provides application guidance that is an integral part of IFRS 16. For instance, ED2013 requires an entity to identify whether a contract is, or contains, a lease and provides some guidance on how to identify this (IASB 2013j, paras. 7-19). However, many respondents, especially preparers, auditors, standards setters and enforcement agencies, considered the guidance in ED2013 inadequate and asked for additional guidance on identifying a

\footnotetext{
${ }^{18}$ In this regard, we note that IFRS 3 Business Combinations requires the recognition of a gain on bargain purchase on the initial recognition of assets and liabilities acquired in business combinations (IASB 2013h, para. 34).

19 We adopt the definition of rules in Nelson (2003, 91): rules broadly "include specific criteria, "bright line" thresholds, examples, scope restrictions, exceptions, subsequent precedents, implementation guidance, etc."
} 
lease. ${ }^{20}$ Consider the following comment by European Securities and Markets Authority

(ESMA) in its submission (comment letter\# Leases2.ED.0134) on ED2013:

In order to promote consistent application and limit the potential issues of enforceability that might arise, ESMA encourages the IASB to develop additional guidance on the assessment of the right to control the use of an asset or when protective rights prevent a lessee from being able to direct the use of the asset.

In response to the feedback, the IASB enhanced the application guidance in IFRS 16 on how to identify a lease (IASB 2016b, paras. B9-B31).

As another example, IFRS 16 requires the lease payments to include variable lease payments that are in-substance fixed (IASB 2016b, para. 27). The IASB (2016b, para. B42) provides examples of in-substance fixed lease payments. Also, to provide guidance on low-value leases, the IASB (2016b, paras. B6 and B8) provides examples of low-value underlying assets (e.g., tablets and personal computers, small items of office furniture and telephones) and suggests that “... leases of cars would not qualify as leases of low-value assets...."

Finally, IFRS 16 incorporates scope exclusions for leases of items that are within the scope of other IFRSs, and permits exclusion of leases of other intangibles not covered in other IFRSs (IASB 2016b, paras. 3-4). The IASB acknowledges the lack of conceptual justification for permitting scope exclusion of leases of other intangibles. However, it allows this exclusion because it has not undertaken a comprehensive review of accounting for intangibles (IASB 2016a, para. BC71).

\footnotetext{
${ }^{20}$ These respondents include CPA Australia Limited and Institute of Chartered Accountants Australia (comment letter \#Leases2.ED.0038), Institute of Chartered Accountants of England and Wales (comment letter \#Leases2.ED.0050), Shell International (comment letter \#Leases2.ED.0090), European Securities and Markets Authority (comment letter \#Leases2.ED.0134), New Zealand Accounting Standards Board (comment letter \# Leases2.ED.0151), Siemens (comment letter \# Leases2.ED.0194), Marks \& Spencer (comment letter \# Leases2.ED.0190), KPMG IFRS Limited (comment letter \# Leases2.ED.0199), Securities and Exchange Commission of Brazil (comment letter \# Leases2.ED.0314), Securities and Exchange Board of India (comment letter \# Leases2.ED.0453), Australian Accounting Standards Board (comment letter \# Leases2.ED.0534), Canadian Accounting Standards Board (comment letter \# Leases2.ED.0588), Belgian Accounting Standards Board (comment letter \# Leases2.ED.0594), International Organization of Securities Commissions (comment letter \# Leases2.ED.0621), and Mazars and WeiserMazars (comment letter \# Leases2.ED.0641).
} 


\section{Short-Term and Low Value Leases: Materiality Concept vs. the Cost Constraint}

IFRS 16 allows recognition exemptions for short-term leases and leases of underlying assets that are of low value (IASB 2016b, para. 5). We, however, note that preparers and auditors regularly make materiality judgments while preparing and auditing financial statements. Therefore, instead of providing specific recognition exemptions, the IASB could have relied on the materiality guidance in the Framework, IAS 1 and IAS 8.

The Framework noted the following regarding the recognition of an element of financial statements (IASB 2010c, para. 4.39):

In assessing whether an item meets these [recognition] criteria and therefore qualifies for recognition in the financial statements, regard needs to be given to the materiality considerations discussed in Chapter 3 Qualitative characteristics of useful financial information. (Emphasis added)

IAS 8 provides the following accounting policy exemption (IASB 2013c, para. 8):

IFRSs set out accounting policies that the IASB has concluded result in financial statements containing relevant and reliable information about the transactions, other events and conditions to which they apply. Those policies need not be applied when the effect of applying them is immaterial. (Emphasis added)

Similarly, IAS 1 provides the following disclosure exemption (IASB 2013b, para. 31):

An entity need not provide a specific disclosure required by an IFRS if the information is not material.

The guidance noted above allows the lessee to assess whether the effect of applying the recognition, measurement and disclosure requirements of IFRS 16 would be material, and depart from these requirements in the case of immaterial effect. The IASB also recognises that the lessee can apply the materiality guidance noted above when applying IFRS 16 (IASB 2016a, paras. BC85 and BC86). EFRAG concurred (comment letter \# CL25): 
As such, that raises legitimate concerns as to whether the cost of applying the recognition and measurement approach proposed in the DP to short-term arrangements and arrangements involving non-core assets is likely to exceed the benefits that would arise. We think this is probably a materiality issue; just as small items of capital expenditure on plant and equipment are not capitalised on materiality grounds, so it ought to be acceptable not to apply the 'rights-of-use' approach to relatively short-term leases on materiality grounds.

Several national accounting standards setters $^{21}$ and auditors ${ }^{22}$ made similar observations, arguing that the materiality concept in the Framework and the guideline in IAS 8 for the application of accounting policies were sufficient in this regard. Nonetheless, the IASB specifically excludes short-term leases and leases of low-value underlying assets from the recognition requirements of IFRS 16 (IASB 2016b, para. 5). The IASB does this to mitigate the cost-benefit concerns of preparers (IASB 2016a, paras. BC88-BC90).

Further, instead of relying on the materiality concept in the Framework, IFRS 16 provides specific methods for assessing whether leases are of low-value assets. For example, IFRS 16 contains the following guideline for assessing the value of leases (IASB 2016b, para. B4):

The assessment of whether an underlying asset is of low value is performed on an absolute basis. Leases of low-value assets qualify for the accounting treatment in paragraph 6 regardless of whether those leases are material to the lessee. The assessment is not affected by the size, nature or circumstances of the lessee. Accordingly, different lessees are expected to reach the same conclusions about whether a particular underlying asset is of low value. (Emphasis added)

The IASB had a size threshold of $\$ 5,000$ in mind when it deliberated the threshold for low-value assets, although it does not include this threshold in IFRS 16

${ }^{21}$ These standards setters include the Belgian Accounting Standards Board (comment letter \# CL6), Norwegian Accounting Standards Board (comment letter \# CL36), German Accounting Standards Board (comment letter \# CL64), Financial Reporting Standards Board (comment letter \# CL149), Canadian Accounting Standards Board (comment letter \# CL236), and Australian Accounting Standards Board (comment letter \# CL256).

22 These auditors include Grant Thornton (comment letter \# CL90), Deloitte (comment letter \# CL120), Ernst \& Young (comment letter \# CL139), PricewaterhouseCoopers (comment letter \# CL173), BDO (comment letter \# CL175), Mazars (comment letter \# CL263) and KPMG (comment letter \# CL270). 
(IASB 2016a, para. BC100). The above guidance is inconsistent with the Framework position on materiality (IASB 2010c, para. QC11).

...materiality is an entity-specific aspect of relevance based on the nature or magnitude, or both, of the items to which the information relates in the context of an individual entity's financial report. (Emphasis added)

Materiality being "an entity-specific aspect of relevance", this recognition exemption based on an absolute threshold, without regard to "the size, nature or circumstances of the lessee", could impair the decision usefulness of the lease accounting information of some lessees.

We notice that the IASB did not provide any exemption when it initially developed the accounting requirement for short-term and low-value leases. Table 2 shows how the accounting requirements for these leases evolved from DP2009 to IFRS 16 in response to the feedback of respondents.

\section{Table 2 about here}

Table 2 reveals that the IASB did not reach any preliminary view regarding any exemption for short-term leases in DP2009 (IASB 2009, para. 2.15). It argued that short-term leases may contain material leases, and scope exclusion would create opportunities for lease structuring (IASB 2009, para. 2.19). In response to the cost concerns of lessees and industry trade associations ${ }^{23}$, the IASB allowed measurement exemptions in ED2010 (IASB 2010d, para. 64). However, the respondents to ED2010 argued that the measurement exemption did not give enough cost relief to lessees, as the major costs of applying the new lease accounting model related to the costs and time

${ }_{23}$ These include Nestle (comment letter \# CL18), Hydro Quebec (comment letter \# CL21), Leaseurope (comment letter \# CL29), Exxon Mobil (comment letter \# CL66), FEI (comment letter \# CL215), Association for Financial Professionals (comment letter \# CL218), and Dell (comment letter \# CL229). 
required for identifying, tracking and recognising many short-term leases ${ }^{24}$ (IASB/FASB Staff 2011, para. 76). Considering this feedback, the IASB (2013j, para. 118) allowed recognition exemption for short-term leases in ED2013. While respondents were happy with this exemption, many demanded that exemptions be given for low-value leases also $^{25}$ (IASB/FASB Staff 2013, para. 126). They acknowledged that the concept of materiality could be applied to deal with low-value leases but alleged that the burden of proof required by auditors and regulators would negate the benefit of applying the materiality concept (IASB/FASB Staff 2013, para. 126). In response to this feedback, the IASB allowed recognition exemptions for both short-term leases and low-value lease ${ }^{26}$ (IASB 2016b, para. 5).

\section{Prescriptive Accounting Requirements in lieu of a General Principle}

We note in Table 1 that the IASB is very prescriptive in specifying detailed accounting requirements in IFRS 16. For example, it specifies separate accounting requirements for (a) lease term options, (b) variable lease payments, and (c) the residual value guarantee. The IASB justified the accounting requirements for variable lease

24 These respondents include Holcim Group Support Ltd. (comment letter \# 0025-1850-100), the Joint Accounting Bodies of Australia (comment letter \#0050-1850-100), Dutch Accounting Standards Board (comment letter \#0055-1850-100), Siemens (comment letter \#0107-1850-100), Commonwealth Bank of Australia (comment letter \#0166-1850-100), Daimler AG (comment letter \#0759-1850-100), and International Organization of Securities Commissions (comment letter \#0777-1850-100).

25 Respondents demanding this include Fleet Leasing Industry (comment letter \# Leases2.ED.0115), Swire Pacific (comment letter \# Leases2.ED.0568), Cathay Pacific (comment letter \# Leases2.ED.0613), and European Financial Reporting Advisory Group (comment letter \# Leases2.ED.0618).

${ }^{26}$ Pertinently, FASB Topic 842 does not allow an exemption for leases of low-value assets (FASB 2016); the concept of materiality applies to financial statements (Wilson 2016). This is notwithstanding the fact that many respondents from the U.S. expressed concerns about the cost of implementing the lease accounting standard for low value leases and asked for the exemption of low value leases from the scope of Topic 842. These U.S. respondents include Financial Executives International (comment letter \# Leases2.ED.0002), Aerospace Industries Association (comment letter \# Leases2.ED.0031), Coldspring (comment letter \# Leases2.ED.0034), and Johnson \& Johnson (comment letter \# Leases2.ED.0042). 
payments and residual payments by referring to the definitions of an asset and a liability (IASB 2016a, paras. BC164, BC165 and BC170). On the other hand, it referred to decision-usefulness and constituents' feedback to justify the accounting requirement for lease term option (IASB 2016a, paras. BC156 and BC157).

The central question underlying these lease accounting issues is how to account for the relevant lease payments. Therefore, drawing on the asset and liability definitions, the IASB could have developed a general principle covering these payments and left the application of this principle to preparers, auditors and IFRS enforcement agencies. This would have obviated the need for specifying these separate requirements and simplified the lease accounting requirements.

The IASB probably chose to specify accounting requirements for each of these lease accounting issues in order to communicate precisely the accounting requirements to preparers, auditors and enforcement agencies in different jurisdictions, and to avoid the emergence of divergent accounting practices on these issues. ${ }^{27}$ Also, based on our finding that constituents asked for additional guidance in areas (e.g., variable lease payments) where the IASB specified the accounting requirement but the guidance in due process documents was considered inadequate, it could be argued that had it not specified the treatments of these lease accounting issues, constituents would have probably asked the IASB to specify them.

\section{APPLYING THE CONCEPTS TO DERIVE ACCOUNTING REQUIREMENTS}

\footnotetext{
${ }^{27}$ The FASB $(2002,9)$ notes that variation in accounting practices is a cost of principles-based standards. We, however, notice in Table 1 that the current requirements also require judgments and may give rise to divergent practices. For example, IFRS 16 requires the lease term to include the optional period if it is reasonably certain that the lessee would exercise the option, and the lease payments to include the variable lease payments that are in-substance fixed (IASB 2016b, paras. 18 and 27). Preparers, auditors and enforcement agencies will have to exercise professional judgments to determine when the exercise of the option is reasonably certain, and which payments are in-substance fixed.
} 
In this section, we examine how the IASB applied the Framework concepts in developing the accounting requirements in IFRS 16 . With this end in view, we focus on three lease accounting requirements - the right-of-use model, the measurement basis and accounting for lease term options.

\section{The Right-of-Use Model: Asset and Liability Definitions, and Constituents' Re- action}

Drawing on the asset and liability definitions, the IASB develops a right-of-use model in IFRS 16. This model requires the lessee to recognise a right-of-use asset and a lease liability for all leases, except for short-term and low-value leases (IASB 2016b, paras. 5 and 22). This contrasts with the IAS 17 model, under which the lessee was required to recognise assets and liabilities for finance leases but did not have to recognise any asset and liability for operating leases ${ }^{28}$ (IASB 2013e, para. 33).

Constituents' responses on DP2009 show that many constituents, especially lessees and industry trade associations, disagreed with the right-of-use model. The major criticism of the model was that operating leases are executory contracts, which are generally not recognised in accounting. Therefore, recognising a right-of-use asset for an operating lease is inconsistent with the accounting for other executory contracts. ${ }^{29}$ Other criticisms included: (a) expanded disclosures could mitigate the deficiency of IAS

28 We note that the finance lease/operating lease distinction in IAS 17 was based on the substance over form principle (IASB 2013e). Finance leases were considered in-substance purchases; therefore, the lessee was required to recognise the leased asset and the lease liability for finance leases. However, there was no IASB Framework in 1982, when the IASC first released IAS 17. IAS 17 lease accounting model was very similar to that of FASB Statement of Financial Accounting Standard No. 13, Accounting for Leases (JIWGL 2007, paras 67-68).

${ }^{29}$ Respondents making this argument include ACTEO (comment letter \# CL25), Department of Finance and Deregulation, Australia (comment letter \# CL40), Conseil National de la Comptabilité (comment letter \# CL74), Emerson Electric (comment letter \# CL109), Tesco (comment letter \# CL167), and UBS (comment letter \# CL171). 
$17,{ }^{30}$ (b) the right-of-use model does not distinguish between economically dissimilar

leases, ${ }^{31}$ and (c) the model will have negative economic consequences on the lessee and

the leasing industry. ${ }^{32}$ As an example of the negative consequences argument, Accor

Group made the following comment in its submission (comment letter \# CL163) on

DP2009:

We regret that the boards confined to a purely accounting analysis of leases without ever wondering about the economic and financial consequences of their proposed approach especially in the current difficult financial context. ..., the application of this new approach will entail significant impacts on the entities' ratios (in particular on Gearing and WACC) because the debts displayed in the statement of financial positions will strongly increase. This increase will not be without consequence on the entities' ratings, on their debt capacities, on their stock-exchange rating and especially on their obligation to hold additional equity (in particular for banking entities). This new approach could have strong significant repercussions on the entities' financing and also on financial markets, especially in the current economic environment. (Emphasis omitted)

We note that many lessees and industry trade associations continued to voice their concerns about the right-of-use model in their submissions on ED2010 and ED2013. Although ED2013 appeared to assume that the issue of the desirability of the right-of-use model was settled and hence did not include any question about the model for constituents to comment on, many lessees and industry trade associations expressed their concerns about it. ${ }^{33}$ For example, comment letter \# Leases2.ED.0010A, which was

30 Respondents making this argument include Department of Finance and Deregulation, Australia (comment letter \# CL40), U.S. Realty Advisors LLC (comment letter \# CL50), E. ON AG (comment letter \# CL85), Air Products and Chemicals Inc (comment letter \# CL108), and U.S. Steel (comment letter \# CL245).

${ }^{31}$ Respondents making this argument include Conseil National de la Comptabilité (comment letter \# CL74), VMEBF e. V. (comment letter \# CL75), Equipment Leasing and Finance Association (ELFA) (comment letter \# CL89), European Association of Cooperative Banks (EACB) (comment letter \# CL114), IATA and AWG (comment letter \# CL123). Spanish Rental Association (comment letter \#CL136), Hewlett-Packard (comment letter \# CL208), and French Banking Federation (comment letter \# CL237).

32 Respondents making this claim include Stuttgart Chamber of Industry and Commerce (comment letter \# CL1), Asociación Española de Leasing (comment letter \# CL30), Association of German Public Sector Banks (comment letter \# CL42), Celanse (comment letter \# CL69), ANIASA (comment letter \# CL81), and Wesfarmers Limited (comment letter \# CL158).

${ }^{33}$ Respondents who expressed concerns about the right-of-use model in their submissions on ED2013 include Financial Executives International (comment letter \# Leases2.ED.0002), Wesfarmers (comment letter \# Leases2.ED.0091), Beacon Rail Leasing (comment letter \# 
submitted collectively by a group of U.S. and non-U.S. industry trade associations on ED2013, raised several concerns about the proposed lease accounting standard and summarised their concerns as follows:

To briefly summarize our concerns, we believe that the proposed leasing standard may increase financial reporting complexity, impose substantial costs on businesses, lack any benefits for investors and drive economic activity rather than reflect it.

However, although they had reservations about the implementation aspects of the right-of-use model, many national standards setters supported it. ${ }^{34}$ The standards setters make the standards-setting decisions for their respective jurisdictions and are, therefore, important for the legitimacy of the IASB (Camfferman and Zeff 2018).

Further, users supported the right-of-use model. In its submission (comment letter \# CL199) on the DP2009, Standard \& Poor's provided the following user perspective on the right-of-use model:

We believe the most significant impact of the new model will be to remove the accounting distinction between operating and finance leases (also referred to as capital leases), placing obligations formerly classified as operating leases on the balance sheet - a result we very much support. We have long viewed the accounting distinction between operating and finance leases as substantially artificial because, in both cases, the lessee contracts for the use of an asset, entering into a debt-like obligation to make periodic rental payments. As a result, we historically have adjusted reported amounts to eliminate the operating or financing distinction by capitalizing lease obligations accounted for as operating leases....We expect the proposed model to improve the financial reporting of the underlying economics of leasing transactions, and provide better, decision-useful information to financial-statement users than current accounting standards.

Leases2.ED.0096), Fleet Leasing Industry (comment letter \# Leases2.ED.0115), Bundesverband Deutscher Leasing-Unternehmen (comment letter \# Leases2.ED.0116), Japan Leasing Association (comment letter \# Leases2.ED.0141), United States Steel Corporation (comment letter \# Leases2.ED.0174), Leaseurope (comment letter \# Leases2.ED.0586), and Cathay Pacific (comment letter \# Leases2.ED.0613).

34 These standard setters include Organismo Italiano di Contabilita (comment letter \# CL14), the Danish Accounting Standards Committee (comment letter \# CL32), Norwegian Accounting Standards Board (comment letter \# CL36), Accounting Standards Board of Japan (comment letter \# CL41), German Accounting Standards Board (comment letter \# CL64), Financial Reporting Standards Board (comment letter \# CL149), Korea Accounting Standards Board (comment letter \# CL164), Brazilian Accounting Pronouncements Committee (comment letter \# CL222), Canadian Accounting Standards Board (comment letter \# CL236), Australian Accounting Standards Board (comment letter \# CL256), UK Accounting Standards Board (comment letter \# CL261), and EFRAG (comment letter \# CL269). 
Similarly, the CFA Institute expressed its support for the capitalisation of operating lease obligations in emphatic terms in its submission (comment letter \# Leases2.ED.0620) on ED2013:

Our support for capitalization of lease obligations is a longstanding position that can be traced back to the 1970s, when our predecessor organization in a comment letter expressed that a requirement to capitalize operating leases would improve the comparability of financial statements. ... Capitalization of leases will enable different market participants (i.e., investors, auditors, academics, preparers) to better assess the lease obligation and, therefore, the total financial leverage of reporting companies. In this respect, capitalization will provide the best opportunity for ongoing improvement to lease accounting and provide data points that allow verification of the value relevance and decision-usefulness of the proposed information. (Footnote omitted)

Consistent with the user primacy concept enshrined in the Framework, the IASB stuck to the right-of-use model. ${ }^{35}$ As Table 1 shows, the primary rationale offered by the IASB for the right-of-use model is that the lessee has the right to use the leased asset during the lease term and an obligation to make payments to the lessor for providing that right, and the right-of-use model faithfully reflects this right and obligation arising out of the lease contract (IASB 2016a, paras. BC19 and BC20). Therefore, the lease accounting information provided by the right-of-use model is relevant (IASB 2013a, para. BC347). The IASB (2016a, para. BC42) also argues that recognising an asset and a liability for all leases will mitigate the concerns of users by putting on the balance sheet all off-balance sheet liabilities provided through operating leases.

One potential explanation for the IASB's continuance with this model lies in the origin of the lease accounting project. Well before the issuance of DP2009, there had

\footnotetext{
35 The user primacy concept is also evident in how the IASB/FASB staff reported the summarised feedback of the respondents on ED2010 and ED2013. For example, in their summary of the feedback on ED2010, the IASB/FASB Staff (2011) reported summarised user feedback under a separate section "User views." They used no such separate section for summarising the preparers' views. Similarly, the IASB/FASB Staff (2013) reported summarised user feedback under "User views" and all other feedback under "Other views". Also, they reported user feedback first, followed by others' feedback. This is notwithstanding the fact that users and preparers represented less than $10 \%$ and more than $50 \%$ of the respondents, respectively, who provided feedback on ED2010 and ED2013 (IASB/FASB Staff 2011, 2013).
} 
been broad agreement among many accounting standards setters and regulators regarding the deficiencies of the IAS 17 lease accounting model. For example, a Special Report, Accounting for Leases: A New Approach, published by the G4+1 Group ${ }^{36}$ in 1996, noted that the distinction between finance and operating leases is arbitrary (McGregor 1996). By according different accounting treatments to these two types of leases, the then lease accounting model encouraged structuring lease transactions and resulted in off-balance sheet liabilities, which reduced the comparability of lease accounting information (McGregor 1996). The IASB Agenda Paper 9A noted these criticisms of the IAS 17 lease accounting model (IASB 2006a, para. 13). The SEC, which controls access to the U.S. capital market and accepts IFRS-based financial statements from foreign issuers without reconciliation to U.S. GAAP, also raised concerns about offbalance sheet arrangements (IASB 2006a, para. 14).

The IASB Staff considered that the IAS 17 lease accounting model could not be improved significantly by minor amendments (IASB 2006a, para. 2). Therefore, it proposed a fundamental review of the lease accounting model based on the rights and obligations generated by leases (IASB 2006a, para. 2). We also note that, well before the issuance of DP2009, many regulators and standard setters proposed new lease accounting models similar to the right-of-use model. For example, the International Organization of Securities Commission (IOSCO), which enhanced the legitimacy of International Accounting Standards (IASs) and the IASC by endorsing a core set of IASs for cross-listing purposes in 2000 (Doupnik and Perera 2015, 73), asked the IASC to consider an alternative lease accounting approach for capitalisation of leases (JIWGL 2007, para. 70). Again, the G4+1 special report advocated a right-of-use model for leases

36 The G4+1 Group was a working group comprised of representatives of accounting standards setting bodies in Australia, Canada, New Zealand, the United Kingdom, and the U.S., and staff of International Accounting Standards Committee (McGregor 1996). The Group produced discussion papers on important accounting issues. It was also politically powerful and exerted pressure for the restructuring of the IASC, which resulted in the replacement of the IASC with the IASB (Camfferman and Zeff 2018; McGregor 2012). 
(McGregor 1996). A second special report in 2000 by the G4+1 Group, Leases:

Implementation of a New Approach, looked at how to incorporate the new approach in an accounting standard (Nailor and Lennard 2000). These criticisms of the existing lease accounting model and the suggestions for a new model by these powerful constituents apparently carried weight with the IASB. The IASB $(2013 \mathrm{j}, 5)$ noted the longstanding support for the right-of-use model in the following words:

The existing accounting models for leases require lessees and lessors to classify their leases as either finance leases or operating leases and account for those leases differently. Those models have been criticised for failing to meet the needs of users of financial statements because they do not always provide a faithful representation of leasing transactions. In particular, they do not require lessees to recognise assets and liabilities arising from operating leases. As a result, there has been a longstanding request from many users of financial statements and others to change the accounting requirements so that lessees would be required to recognise those assets and liabilities.

This genesis of the lease accounting project and the support for the right-of-use model among important international constituents potentially explains why the IASB continued with the concepts-based right-of-use model even in the face of criticisms from preparers and industry trade associations. This suggests that the support of important constituents is important for a private-sector standard-setting body like the IASB to develop principles-based standards. ${ }^{37}$ This further suggests the importance of understanding how standard-setting agendas are determined ${ }^{38}$ (Beresford 1993).

${ }^{37}$ FASB (2002) offers a similar observation with respect to principles-based standard setting in the U.S.

38 There has been some progress in understanding the influences on FASB's agenda decisions. Allen (2014), for example, studies the preferences of Financial Accounting Standards Advisory Committee (FASAC) members and finds that the preferences of FASAC financial members were associated with FASB agenda decisions during 2002-06. However, Johnson and Swieringa (1996) provide case evidence suggesting that FASB's agenda decisions are far more complex than a consideration of the opinions of a constituent group. More importantly, both Beresford (1993) and Johnson and Swieringa (1996) report that the agenda proposals come from many sources, including the American Institute of Certified Public Accountants, the Emerging Issues Task Force, accounting firms, SEC, and various professional and industry-specific organizations. Further, the standard setting environment of the IASB is different from that of the FASB (Camfferman and Zeff 2018). Therefore, future work may investigate the agenda-setting decisions of the FASB and the IASB. 


\section{Measurement: Consistency vs. Relevance and Faithful Representation}

The Framework lists four measurement bases but refrains from providing any guidance on which basis to use for the measurement of financial statement elements (IASB 2010c, para. 4.55). However, the Framework provides a hierarchy of qualitative characteristics, classifying them into fundamental and enhancing qualities (IASB 2010c, paras. QC5 and QC19). It places the fundamental qualities above the enhancing qualities (IASB 2010b, paras. BC3.8 and BC3.10), and suggests that when considering the trade-off between the fundamental qualities of relevance and faithful representation, relevance should be considered first (IASB 2010c, para. QC18). Therefore, the Framework leads us to expect that the IASB would consider relevance and faithful representation more important than the enhancing qualities in choosing the measurement basis for the right-of-use asset and the lease liability.

The IASB considered fair value for the initial measurement of the right-of-use asset but rejected this in favour of cost, measured as the present value of lease payments (IASB 2016a, paras. BC145 and BC148). The following extract from the Basis for Conclusions accompanying IFRS 16 reveals the IASB's considerations for this decision (IASB 2016a, para. BC148).

The IASB considered whether a lessee should initially measure the right-of-use asset at fair value, which may provide more relevant information about the economic benefits to be derived from use of the underlying asset. However, initial measurement of a right-ofuse asset at cost is consistent with the measurement of many other non-financial assets, such as assets within the scope of IAS 16 and IAS 38. Measuring right-of-use assets on a basis similar to that used to measure the underlying asset maintains the comparability of amounts reported for leased and owned assets, which contributes to the usefulness of the information provided to users of financial statements.

So, we see that although the IASB agrees that the fair value may provide more relevant information about the right-of-use asset, it rejected this measurement basis in favour of the cost basis on the grounds of consistency and comparability. Note that consistency per se is not a qualitative characteristic in the Framework. The Framework 
notes that consistency is related to, but not the same as, comparability - one of the four enhancing qualitative characteristics of useful financial information (IASB 2010c, paras. QC19 and QC22). Consistency with other IFRSs achieves comparability in the sense that similar transactions are treated in a similar way. Nevertheless, relying on consistency rather than on relevance to derive accounting requirements violates the hierarchy of qualitative characteristics laid out in the Framework.

More importantly, in areas (e.g., measurement) where the Framework does not provide any normative guidance, using the notion of consistency with other IFRSs to support accounting requirements in a new IFRS may perpetuate prior accounting requirements and impede the development of new accounting requirements in line with concepts of the Framework. Further, we note that the IASB has not applied the consistency notion consistently in deriving lease accounting requirements. For example, although entities can choose between the cost model and the revaluation model for the subsequent measurement of non-financial assets under IAS 16 and IAS 38 (IASB 2013d, 2013g), IFRS 16 does not allow the revaluation model for the right-of-use asset except under specific conditions (IASB 2016b, paras. 29, 34 and 35).

IFRS 16 requires the lease liability to be measured at the present value ${ }^{39}$ of the lease payments (IASB 2016b, para. 26). The IASB considered fair value for the lease liability and noted three advantages thereof: (a) it reflects the current market conditions and hence, provides more useful information than other measures, (b) it is more comparable because it ignores entity-specific information, and (c) it is consistent with the measurement of other financial liabilities (IASB 2009, para. 4.6). However, the IASB

${ }^{39}$ While the Framework lists present value as a measurement basis, the current thinking at the IASB appears to be that it is a measurement technique, which can be used to estimate other measurement bases such as fair value under IFRS 13 and value in use under IAS 36 (IASB 2013f, 2013i). Thus, without specifying the measurement objective for the lease liability, IFRS 16 specifies how to measure it. 
rejected the fair value basis for the lease liability because it is not observable (IASB 2009, para. 4.7).

However, the fact that the fair value of the lease liability is unobservable does not provide an adequate conceptual basis for rejection of the fair value, as it can be estimated. Unobservability affects verifiability, which is an enhancing qualitative characteristic $^{40}$ (IASB 2010c, para. QC19). However, estimates are integral to accounting under IFRSs (IASB 2013b, para. 126). The Framework says that a representation of an estimate can be faithful if it is clearly described as an estimate and the associated assumptions and judgments are disclosed (IASB 2010c, para. QC15). Consistent with this, IFRS 13 requires extensive disclosures for Level 3 fair value measurements (IASB 2013i). Note that we are not advocating a measurement basis here. Rather what we demonstrate is that the IASB was inconsistent in invoking the qualitative characteristics and the reasons IASB cited for specifying the initial measurement basis were not in line with the hierarchy of qualitative characteristics.

\section{Lease Term Options: Liability Definition vs. Structuring Opportunity and Decision Usefulness}

Lease term options are the rights granted to the lessee to extend the lease beyond the non-cancellable lease period or terminate the lease before the expiry of the lease period (IASB 2016a, para. BC152). The accounting issue is how to account for the optional period. IFRS 16 requires the lease term to include the optional period if it is reasonably certain that the lessee will exercise the option (IASB 2016b, para. 18).

We see that the IASB made the standard setting decision on accounting for the lease term option in four steps. Figure 1 shows the accounting alternatives the IASB

40 Note that the IASB initially considered verifiability as an aspect of faithful representation (IASB 2010b, para. BC3.36). To mitigate the concern of constituents that including verifiability as an aspect of faithful representation could lead to the exclusion of information that is not readily verifiable, the IASB re-positioned it as an enhancing quality (IASB 2010b, para. BC3.36). This further reinforces our argument that rejecting the fair value basis for the lease liability on the ground of its unobservability is not consistent with the Framework. 
considered in each step. In the first step, it considered whether to recognise and measure the term option as a separate component of the lease (component approach). Although the option to extend or terminate the lease meets the definition of an asset (IASB 2009, paras. 3.31 and 6.8), the IASB argues that recognising and measuring it as a separate component is complex, ignores the interrelationship between the lease term and the exercise of the option, and is difficult to implement (2010a, para. BC120(a)). Therefore, it decided that instead of accounting for each lease component separately, the lessee should recognise a single lease asset and a single lease liability (IASB 2009, para. $6.8)$.

\section{Figure 1 about here}

In the second step, the IASB considered the alternative of disclosing the existence of the term option in notes, and recognising a right-of-use asset and a lease liability for the non-cancellable lease term (disclosure approach). The IASB (2010a, para. $\mathrm{BC} 120(\mathrm{~b})$; 2013a, para. $\mathrm{BC} 137(\mathrm{~b}))$ argued that although the disclosure approach is simple, it ignores the existence of the option, and hence provides less useful information to users. It therefore rejected this approach, and decided that the right-of-use asset and the lease liability should reflect payments during the optional period.

Having made this decision, in the third step the IASB considered two approaches - the measurement approach and the recognition approach - to reflect the lease term option in the right-of-use asset and the lease liability. Under the measurement approach (probability-weighted measurement), the lease asset and the lease liability would reflect the probability of each possible outcome ${ }^{41}$ (IASB 2009, 2010a, 2013a). While this

\footnotetext{
${ }^{41}$ For example, a lease has a non-cancellable lease term of 10 years, with an option to extend the lease for 5 more years. Annual rentals during both the non-cancellable and the optional periods are $\$ 100$. If the lessee determines that there is an $80 \%$ chance that the option will be exercised,
} 
approach reflects the option better than other methods and mitigates the risk of offbalance sheet liabilities, the IASB argued that it is difficult to measure the probabilities of each outcome (IASB 2009, 2010a, 2013a, 2016a). Therefore, the IASB rejected this approach in favour of the recognition approach (IASB 2009, para. 6.22).

Under the recognition approach, the lessee would recognise the uncertainty regarding the lease term through recognition ${ }^{42}$ (IASB 2009, para. 6.16). Under this approach, the IASB initially considered three methods: (a) the probability threshold method $^{43}$, (b) the qualitative assessment of the lease term ${ }^{44}$, and (c) the most likely lease term $^{45}$ (IASB 2009, para. 6.24). The IASB initially rejected the probability threshold method and the qualitative assessment method, and decided in DP2009 and ED2010 that the most likely lease term ${ }^{46}$ would be used to incorporate the term option in the lease term (IASB 2009, para. 6.36).

However, because of constituents' objections to the most likely lease term approach $^{47}$, the IASB reconsidered it and decided in ED2013 that the lease term must

under the measurement approach the lessee would recognise a lease liability for $\$ 1,400$. $(0.80 * 15 * \$ 100+0.20 * 10 * \$ 100)$. (Adapted from IASB (2009, paras. 6.11 and 6.12)).

42 In the example given in note 41 , the lessee would recognise a lease liability based on either 10 year rentals or 15-year rentals under the recognition approach (IASB 2009, para. 6.16).

${ }^{43}$ Under the probability threshold method, the optional term is included in the lease term if the probability of exercising the option exceeds a defined threshold (IASB 2009, para. 6.26).

${ }_{44}$ Under the qualitative assessment of the lease term approach, the lessee would make a qualitative assessment of the lease term to determine the substantive lease term based on reasonable and supportable assumptions (IASB 2009, para. 6.31).

${ }^{45}$ Under the most likely lease term approach, the lessee would recognise the obligation to pay rentals based on the most likely lease term (IASB 2009, para. 6.34).

46 DP2009 proposed the most likely lease term, meaning the lease term with the highest probability (IASB 2009, para. 6.35). ED2010, on the other hand, proposed the longest possible lease term that is more likely than not to occur (IASB 2010a, para. BC118). While the lease terms under these two methods may not be the same, ED2013 put them together under the most likely approach (IASB 2013a, para. BC138). Further, both approaches have similar advantages and disadvantages. Therefore, we put them under the most likely approach.

47 These respondents include Holcim Group Support Ltd (comment letter \# 0025-1850-100), Cathay Pacific (comment letter \# 0027-185-100), Swedish Financial Reporting Board (comment letter \# 0029-1850-100), the Joint Accounting Bodies of Australia (comment letter \# 0050-1850- 
include the option to extend (terminate) the lease if the lessee has significant incentives (not) to exercise the option (IASB 2013a, para. BC140; 2013j, para. 25). Constituents were still concerned that the concept "significant economic incentives" was new and might be difficult to implement. They suggested that the IASB retain the concept "reasonably certain" in IAS 17 because they claimed that the concept was wellunderstood $^{48}$ (IASB 2016a, para. BC156(b) ). On receiving this feedback, the IASB switched from the "significant economic incentives" concept in ED2013 to the "reasonably certain" concept in IFRS 16 (IASB 2016a, para. BC157), and requires the lease term to include the option to extend (terminate) the lease term if the lessee is reasonably certain (not) to exercise the option to extend (terminate) it (IASB 2016b, para. 18). Table 3 reports these alternatives, the arguments the IASB provided for and against each alternative, the IASB's choice from among these alternatives, and its justification.

\section{Table 3 about here}

We argue that the central issue in this decision process should have been whether payments during the optional period meet the definition of a liability. The Framework says that general purpose financial reports provide information about the entity's economic resources and the claims against the entity (IASB 2010c, para. OB12).

100), Dutch Accounting Standards Board (comment letter \# 0055-1850-100), PricewaterhouseCoopers LLP (comment letter \# 0063-1850-100), Deutsche Telekom AG (comment letter \# 0099-1850-100), Siemens (comment letter \# 0107-1850-100) and Woolworths Limited (comment letter \# 0229-1850-100).

${ }^{48}$ Respondents who made this suggestion in their submissions on ED2013 include CPA Australia Ltd and Institute of Chartered Accountants of Australia (comment Letter \# Leases2.ED.0038), Wesfarmers (comment Letter \# Leases2.ED.0091), Japan Leasing Association (comment Letter \# Leases2.ED.0141), KPMG IFRS Limited (comment Letter \# Leases2.ED.0199), BT Group (comment Letter \# Leases2.ED.0537), Financial reporting Council (comment Letter \# Leases2.ED.0609), EFRAG (comment Letter \# Leases2.ED.0618), Nestle S.A. (comment Letter \# Leases2.ED.0633), and Mazars and WeiserMazars (comment Letter \# Leases2.ED.0641). 
It further notes that information about existing claims helps users predict future cash flows, which is the central objective of financial reporting (IASB 2010c, paras. OB3, OB4 and OB13). Therefore, determining whether payments during the optional period meet the definition of a liability is critically important.

The Framework defined a liability as follows (IASB 2010c, para. 4.4(b)):

A liability is a present obligation of the entity arising from past events, the settlement of which is expected to result in an outflow from the entity of resources embodying economic benefits.

The key issue here is whether the lessee has a present obligation based on an obligating event. The Framework notes that the future expectation of a payment per se does not make it a liability (IASB 2010c, para. 4.16). To be a liability, there must be an obligating event (IASB 2010c, paras. 4.16 and 4.18), which, in the case of a lease term option, is the exercise of the option. Many constituents argued that the lessee did not have a present obligation for payments during the optional period before exercising the option $^{49}$ (IASB/FASB Staff 2009a, 2011).

The IASB (2016a, para. BC154) acknowledged this argument. It also noted: “---it can be argued that the lessee's obligation to pay rentals in an optional period does not meet the definition of a liability" (IASB 2009, para. 6.8). The IASB/FASB Staff (2009b, paras. 32-33) acknowledged that including the term option in the lease term would result "in the recognition of a liability that may include amounts that the lessee can avoid paying (i.e., payments during optional periods)". However, without resolving this central issue, the IASB (2016a, para. BC156) argues that the lease term should reflect the entity's reasonable expectation of what the lease term would be because that provides the most useful information. The IASB/FASB Staff (2009b, paras. 32-33) argue that excluding the term option from the lease term would result in understated assets

49 Respondents making this argument include Deutsche Telekom (comment letter \# Leases2.ED.0164), Lafarge (comment letter \# Leases2.ED.0190), and Marks \& Spencer (comment letter \# Leases2.ED.0190). 
and create structuring opportunities. The Framework, however, explicitly says that to recognise an item, it must meet the definition of an element of financial statements (IASB 2010c, para. 4.38). Thus, the requirement to recognise the lease term option runs contrary to the Framework.

Comments by the IASB/FASB Staff (2009b, paras. 32-33) appear to suggest that the IASB's decision to require payments during the optional period to be included in the lease liability was driven, in part, by its desire to mitigate potential lease-structuring opportunities. It may be asked whether structuring opportunities are best addressed through accounting standards. This question is important because, in the discussion of principles-based standards, the regulatory literature emphasizes the role of preparers and auditors in applying accounting standards in line with the principles and objectives, and the economic substance of transactions (FASB 2002; SEC 2003).

\section{IMPLICATIONS, FUTURE RESEARCH OPPORTUNITIES AND LIMITATIONS}

We examined how the IASB applied the Framework in developing IFRS 16. Although the IASB cited the Framework concepts to justify accounting requirements, we find one instance where it used an outside-the-Framework notion. Further, the IASB introduced rules in IFRS 16 in response to demands from constituents, especially lessees and industry trade associations, and reduced the implementation cost. However, we find instances where the IASB did not apply appropriate concepts in specifying lease accounting requirements. More specifically, instead of relying on the fundamental qualitative characteristics of relevance and faithful representation, the IASB cited consistency and the unobservability of fair value to justify the initial measurement basis for the right-of-use asset and the lease liability, respectively. Also, the IASB did not rely on the definition of a liability to specify the accounting for lease term options. Such deviations erode the status and usefulness of the Framework, and undermine the 
cohesiveness of IFRSs, create complexity and likely compromise the decision-usefulness of the resulting financial information. Therefore, we feel that there is a strong need for the IASB to apply the Framework rigorously in setting IFRSs, although the standardsetting environment is highly political ${ }^{50}$ (Mellado and Parte 2017; Pelger and Spiess 2017).

While it is important for the IASB to use the Framework concepts in setting IFRSs, it is more important to use appropriate concepts. For example, the IASB committed itself to a hierarchy of qualitative characteristics of accounting information. However, contrary to this hierarchy, the IASB used the consistency notion to justify lease accounting requirements. Since not all extant IFRS requirements are in line with the Framework (Nobes 2005), using the consistency notion to derive accounting requirements in new IFRSs may endanger the conceptual coherence of IFRSs.

Our paper highlights the need for further research in accounting standard setting. For example, we noted that respondents both in the U.S. and elsewhere asked for exemption of low value leases from the lease accounting standard. The IASB acceded to these demands but the FASB did not. Given that the costs and benefits of accounting standards are not amenable to precise quantitative assessments, understanding how the standard setters weigh respondents' feedback will further enhance our understanding of the standard setting process. Future research may also examine whether standard setting decisions vary depending on whether the IASB develops IFRSs alone or jointly with the FASB.

\footnotetext{
50 The history of accounting standard setting in the U.S. is replete with examples of controversies surrounding conceptually deficient accounting requirements. Examples include the pooling-ofinterests method (Hong, Kaplan, and Mandelker 1978) and the accounting for stock compensations (Young 2014). We also note that the failure of the Committee on Accounting Procedures and the APB was attributed, in part, to their failure to come up with concepts-based accounting standards (Moonitz 1974). These illustrate the potential danger of conceptually deficient accounting standards.
} 
Finally, one limitation of the study is that it does not identify the informal, indirect lobbying activities that may have been the reason for some of the IASB decisions (Mellado and Parte 2017). 


\section{REFERENCES}

Abela, M., R. Barker, R. Sommer, A. Teixeira, and P. André. 2014. Towards a new conceptual framework: Presentations at the Accounting in Europe and European Accounting Association Financial Reporting Standards Committee Symposium. Accounting in Europe 11 (2): 259-271.

Accounting Principles Board (APB). 1970. Basic Concepts and Accounting Principles Underlying Financial Statements of Business Enterprises. APB Statement No. 4. New York: American Institute of Certified public Accountants.

Allen, A. M. 2014. Agenda setting at the FASB: Evidence from the role of the FASAC. Harvard Business School Accounting \& Management Unit. Available at: https://papers.ssrn.com/sol3/papers.cfm?abstract_id=2533184

American Accounting Association Financial Accounting Standards Committee (AAAFASC). 2003. Evaluating concepts-based vs. rules-based approaches to standard setting. Accounting Horizons 17 (1): 73-89.

André, P., A. Cazavan-Jeny, W. Dick, C. Richard, and P. Walton. 2009. Fair value accounting and the banking crisis in 2008: Shooting the messenger. Accounting in Europe 6 (1): 3-24.

Bamber, M., and K. McMeeking. 2016. An examination of international accounting standard-setting due process and the implications for legitimacy. The British Accounting Review 48 (1): 59-73.

Barker, R. 2015. Conservatism, prudence and the IASB's conceptual framework. Accounting and Business Research 45 (4): 514-538.

Bauer, A. M., P. C. O'Brien, and U. Saeed. 2014. Reliability makes accounting relevant: a comment on the IASB Conceptual Framework project. Accounting in Europe 11 (2): 211-217.

Beresford, D. R. 1988. The 'balancing act' in setting accounting standards. Accounting Horizons 2 (1): 1-7.

1993. Frustrations of a standards setter. Accounting Horizons 7 (4): 70-76.

2001. Congress looks at accounting for business combinations. Accounting Horizons 15 (1): 73-86.

Bhimani, A. 2008. The role of a crisis in reshaping the role of accounting. Journal of Accounting and Public Policy 27 (6): 444-454.

Brouwer, A., A. Faramarzi, and M. Hoogendoorn. 2014. Does the new conceptual framework provide adequate concepts for reporting relevant information about performance? Accounting in Europe 11 (2): 235-257.

Brouwer, A., M. Hoogendoorn, and E. Naarding. 2015. Will the changes proposed to the conceptual framework's definitions and recognition criteria provide a better basis for IASB standard setting? Accounting and Business Research 45 (5): 547-571.

Camfferman, K., and S. A. Zeff. 2018. The Challenge of Setting Standards for a Worldwide Constituency: Research Implications from the IASB's Early History. European Accounting Review 27 (2): 289-312.

Christensen, J. 2010. Conceptual frameworks of accounting from an information perspective. Accounting and Business Research 40 (3): 287-299.

Committee to Prepare a Statement of Basic Accounting Theory. 1966. A Statement of Basic Accounting Theory [ASOBAT]. Sarasota, Florida: American Accounting Association

Cortese, C., and H. Irvine. 2010. Investigating international accounting standard setting: The black box of IFRS 6. Research in Accounting Regulation 22 (2): 87 95. 
Cortese, C. L., H. J. Irvine, and M. A. Kaidonis. 2010. Powerful players: How constituents captured the setting of IFRS 6, an accounting standard for the extractive industries. Accounting Forum 34 (2): 76-88.

Cuijpers, R., and W. Buijink. 2005. Voluntary adoption of non-local GAAP in the European Union: A study of determinants and consequences. European Accounting Review 14 (3): 487-524.

Doupnik, T., and H. Perera. 2015. International Accounting. Fourth ed. New York.: McGraw Hill Education.

Financial Accounting Standards Board (FASB). 2002. Proposal, Principles-Based Approach to US Standard Setting. Available at: https://www.fasb.org/cs/Satellite?c=Document_C\&cid=1176157522715\&d=Touch \&pagename=FASB $\% 2$ FDocument_C\%2FDocumentPage

- 2004. FASB Response to SEC Study on the Adoption of a Principles-Based Accounting System. Available at: http://www.fasb.org/response sec study july2004.pdf

2016. FASB Accounting Standards Update No. 2016-02 Leases (Topic 842).

2017. The Conceptual Framework: Who Benefits From A Framework And Why Is It Needed? 2017. Available at: http://www.fasb.org/jsp/FASB/Page/BridgePage\&cid=1176168367774\#section 3

Francis, J. R. 1987. Lobbying against proposed accounting standards: The case of employers' pension accounting. Journal of Accounting and Public Policy 6 (1): 3557.

Gaa, J. C. 1988. Methodological Foundations of Standard setting for Corporate Financial Reporting. In Studies in Accounting Research Sarasota, Florida.

Gebhardt, G., A. Mora, and A. Wagenhofer. 2014. Revisiting the fundamental concepts of IFRS. Abacus 50 (1): 107-116.

Giner, B., and M. Arce. 2012. Lobbying on accounting standards: Evidence from IFRS 2 on share-based payments. European Accounting Review 21 (4): 655-691.

Hong, H., R. S. Kaplan, and G. Mandelker. 1978. Pooling vs. purchase: The effects of accounting for mergers on stock prices. The Accounting Review 53 (1): 31-47.

IFRS Foundation. 2016a. Due Process Handbook. Available at: http://www.ifrs.org//media/feature/about-us/legal-and-governance/constitution-docs/due-processhandbook.pdf?la=en\&hash=E301B3030818C11E7E5A8A256745C66145E9C480

2016b. IFRS Foundation Constitution. Available at: http://www.ifrs.org//media/feature/about-us/legal-and-governance/constitution-docs/ifrs-foundationconstitution.pdf?la=en\&hash=6152EE0474D3331AC616CDA581DDE9FF3E2A34 $\underline{50}$

Imhoff Jr, E. A., and J. K. Thomas. 1988. Economic consequences of accounting standards: The lease disclosure rule change. Journal of Accounting and Economics 10 (4): 277-310.

International Accounting Standards Board (IASB). 2006a. Information for Observers Project: Leases, Subject: Agenda Proposal - Leasing (Agenda Proposal 9A). Available at: $\quad$ http://archive.ifrs.org/Current-Projects/IASBProjects/Leases/Pages/Leases.aspx

2006b. Preliminary Views on an improved Conceptual Framework for Financial Reporting: The Objective of Financial Reporting and Qualitative Characteristics of Decision-useful Financial Reporting Information. Available at: http://archive.ifrs.org/Current-Projects/IASB-Projects/ConceptualFramework/DPJul06/Documents/DP_ConceptualFramework.pdf 2008. Exposure Draft of An Improved Conceptual Framework for Financial Reporting. Available at: http://archive.ifrs.org/Current-Projects/IASB- 
Projects/Conceptual-

Framework/EDMay08/Documents/conceptual_framework_exposure_draft.pdf

. 2009. Leases Preliminary Views, Discussion Paper DP/2009/1. Available at: http://archive.ifrs.org/Current-Projects/IASB-

Projects/Leases/DPMar09/Documents/DPLeasesPreliminaryViews.pdf

. 2010a. Basis for Conclusions Exposure Draft ED/2010/9 Leases. Available at: http://www.ifrs.org/Current-Projects/IASB-

Projects/Leases/ed10/Documents/EDLeasesBasis0810.pdf (last accessed August 26, 2016).

2010b. Basis for Conclusions on Chapter 3: Qualitative characteristics of useful information.

2010c. The Conceptual Framework for Financial Reporting.

2010d. Exposure Draft ED/2010/9 Leases. Available at:

http://archive.ifrs.org/Current-Projects/IASB-

Projects/Leases/ed10/Documents/EDLeasesStandard0810.pdf

2012. Feedback Statement: Agenda Consultation 2011. Available at: http://archive.ifrs.org/Current-Projects/IASB-Projects/IASB-agendaconsultation/Documents/Feedback-Statement-Agenda-Consultation-Dec-2012.pdf 2013a. Basis for Conclusions Exposure Draft ED/2013/6 Leases. Available at: http://archive.ifrs.org/Current-Projects/IASB-Projects/Leases/Exposure-DraftMay-2013/Documents/ED-Leases-Basis-for-Conclusions-May-2013.pdf

2013b. International Accounting Standard 1 Presentation of Financial Statements. In $A$ Guide through IFRS. London, United Kingdom: IFRS Foundation.

. 2013c. International Accounting Standard 8 Accounting Policies, Changes in Accounting Estimates and Errors. In A Guide through IFRS. London, United Kingdom: IFRS Foundation.

2013d. International Accounting Standard 16 Property, Plant and Equipment. In $A$ Guide through International Financial Reporting Standards. London, United Kingdom: IFRS Foundation.

2013e. International Accounting Standard 17 Leases. In A Guide through IFRS. London, United Kingdom: IFRS Foundation.

. 2013f. International Accounting Standard 36 Imapirment of Assets. In A Guide through IFRS. London, United Kingdom: IFRS Foundation.

. 2013g. International Accounting Standard 38 Intangible Assets. In A Guide through IFRS. London, United Kingdom: IFRS Foundation.

. 2013h. International Financial Reporting Standard 3 Business Combinations. In A Guide through IFRS. London, United Kingdom: IFRS Foundation.

. 2013i. International Financial Reporting Standard 13 Fair Value Measurement. In $A$ Guide through IFRS. London: IFRS Foundation.

2013j. Leases, Exposure Draft ED/2013/6. Available at: http://archive.ifrs.org/Current-Projects/IASB-Projects/Leases/Exposure-Draft-

May-2013/Documents/ED-Leases-Standard-May-2013.pdf

. 2013k. A Review of the Conceptual Framework for Financial Reporting, Discussion Paper DP/2013/1. Available at: https://www.ifrs.org//media/project/conceptual-framework/discussion-paper/published-documents/dpconceptual-framework.pdf

2015. Conceptual Framework for Financial Reporting, Exposure Draft ED/2015/3. Available at: https://www.ifrs.org/-/media/project/conceptualframework/exposure-draft/published-documents/ed-conceptual-framework.pdf

2016a. Basis for Conclusions IFRS 16 Leases. Available at: https://www.ifrs.org/issued-standards/ 
2016b. IFRS 16 Leases. Available at: https://www.ifrs.org/issued-standards/listof-standards/

2. 2018. Conceptual Framework for Financial Reporting. Available at: https://www.ifrs.org/issued-standards/list-of-standards/

International Accounting Standards Board (IASB)/Financial Accounting Standards

Board (FASB) Staff. 2009a. IASB/FASB Staff Paper for IASB Meeting 15

September 2009 FASB Meeting 16 September 2009 - Project: Leases, Topic:

Comment Letter Summary, IASB Agenda reference 6A, FASB memo reference

38. Available at: $\mathrm{http}$ ://archive.ifrs.org/Current-Projects/IASB-

Projects/Leases/Pages/Board-discussions-3.aspx

2009b. IASB/FASB Staff Paper for IASB/FASB Joint Meeting 18 November 2009

- Project: Leases, Topic: Lessee Accounting - Leases with options, IASB Agenda

reference 5D, FASB memo reference 49. Available at:

http://archive.ifrs.org/Current-Projects/IASB-Projects/Leases/Pages/Board-

discussions-3.aspx

2011. IASB/FASB Staff Paper for IASB/FASB Meeting January 2011 - Project:

Leases, Topic: Comment Letter Summary - main issues, IASB Agenda reference

5A, FASB Memo 123. Available at: http://archive.ifrs.org/Current-Projects/IASB-

Projects/Leases/Pages/Board-discussions-4.aspx

2013. IASB/FASB Staff Paper for FASB/IASB Meeting November 2013 - Project:

Leases, Topic: Summary of feedback on the 2013 ED, IASB Agenda ref 3A, FASB

Agenda ref 259. Available at: http://archive.ifrs.org/Current-Projects/IASB-

Projects/Leases/Pages/Discussion-and-papers-stage-5.aspx

Johnson, L. T., and R. J. Swieringa. 1996. Anatomy of an agenda decision: statement no. 115. Accounting Horizons 10 (2):149-179.

Joint International Working Group on Leasing (JIWGL). 2007. History of Lease Accounting. Available at: http://archive.ifrs.org/Current-Projects/IASBProjects/Leases/Meeting-Summaries-and-Observer-Notes/Documents/Obs2.pdf

Jorissen, A., N. Lybaert, R. Orens, and L. van der Tas. 2012. Formal participation in the IASB's due process of standard setting: a multi-issue/multi-period analysis. European Accounting Review 21 (4): 693-729.

2013. A geographic analysis of constituents' formal participation in the process of international accounting standard setting: Do we have a level playing field? Journal of Accounting and Public Policy 32 (4): 237-270.

Kelly, L. 1985. Corporate management lobbying on FAS No. 8: Some further evidence. Journal of Accounting Research 23(2): 619-632.

Lys, T., and L. Vincent. 1995. An analysis of value destruction in AT\&T's acquisition of NCR. Journal of Financial Economics 39 (2-3): 353-378.

Macve, R. 2010. Conceptual frameworks of accounting: Some brief reflections on theory and practice. Accounting and Business Research 40 (3): 303-308.

McGregor, W. 1996. Accounting for Leases: A New Approach. In Financial Accounting Series. Available at: http://archive.ifrs.org/Current-Projects/IASBProjects/Leases/Documents/FASBSR-1996-Leases-New-Approach.pdf 2012. Personal reflections on ten years of the IASB. Australian Accounting Review 22 (3): 225-238.

Mellado, L., and L. Parte. 2017. Determinants of corporate lobbying intensity in the lease standard-setting process. Spanish Accounting Review 20 (2): 131-142. https://doi.org/10.1016/j.rcsar.2016.09.001

Moonitz, M. 1961. The Basic Postulates of Accounting. In Accounting Research Study New York: American Institute of Certified Public Accountants. 
1974. Obtaining Agreement on Standards in the Accounting Profession. In Studies in Accounting Research Sarasota, Florida: American Accounting Association.

Nailor, H., and A. Lennard. 2000. Leases: Implementation of a New Approach In Financial Accounting Series. Available at: http://archive.ifrs.org/CurrentProjects/IASB-Projects/Leases/Documents/FASBSR-2000-LeasesImplementation-Of-New-Approach.pdf

Nelson, M. W. 2003. Behavioral evidence on the effects of principles-and rules-based standards. Accounting Horizons 17 (1): 91-104.

Nelson, M. W., J. A. Elliott, and R. L. Tarpley. 2002. Evidence from auditors about managers' and auditors' earnings management decisions. The Accounting Review 77 (Supplement): 175-202.

Nobes, C. W. 2005. Rules-based standards and the lack of principles in accounting. Accounting Horizons 19 (1): 25-34.

Nobes, C. W., and C. Stadler. 2015. The qualitative characteristics of financial information, and managers' accounting decisions: Evidence from IFRS policy changes. Accounting and Business Research 45 (5): 572-601.

Pelger, C., and N. Spiess. 2017. On the IASB's construction of legitimacy-The case of the agenda consultation project. Accounting and Business Research 47 (1): 64-90.

Puro, M. 1984. Audit firm lobbying before the Financial Accounting Standards Board: An empirical study. Journal of Accounting Research 22 (2): 624-646.

Schipper, K. 2003. Principles-based accounting standards. Accounting horizons 17 (1):61-72.

Securities and Exchange Commission (SEC). 2003. Study pursuant to Section 108(d) of the Sarbanes-Oxley Act of 2002 on the adoption by the United States financial reporting system of a principles-based accounting system. Available at: https://www.sec.gov/news/studies/principlesbasedstand.htm

. 2007. Acceptance from Foreign Private Issuers of Financial Statements Prepared in Accordance With International Financial Reporting Standards without Reconciliation to U.S. GAAP. Available at: https://www.sec.gov/rules/final/2007/33-8879.pdf

Solomons, D. 1978. The politicization of accounting. Journal of Accountancy (pre-1986) (November): 65-72.

Sprouse, R. T., and M. Moonitz. 1962. A Tentative Set of Broad Accounting Principles for Business Enterprises. In Accounting Research Study New York: American Institute of Certified Public Accountants.

Study Group on the Objectives of Financial Statements. 1973. Objectives of Financial Statements: AICPA, New York.

van Mourik, C. 2014. The equity theories and the IASB conceptual framework. Accounting in Europe 11 (2): 219-233.

Watts, R. L., and J. L. Zimmerman. 1978. Towards a positive theory of the determination of accounting standards. Accounting review LIII (1): 112-134.

Wells, M. J. 2011. Framework-based approach to teaching principle-based accounting standards. Accounting Education 20 (4): 303-316.

Wilson, S. 2016. Leases - Understanding the impact of the new standard. Available at: https://home.kpmg.com/content/dam/kpmg/pdf/2016/06/KPMG-Ignite-Leasesunderstnading-the-impact-of-the-new-standard.pdf

Young, J. J. 2014. Separating the Political and Technical: Accounting Standard-Setting and Purification. Contemporary Accounting Research 31 (3): 713-747.

Zeff, S. A. 1978. The rise of "economic consequences". The Journal of Accountancy (December): 56-63. 
- 2002. "Political" lobbying on proposed standards: A challenge to the IASB. Accounting Horizons 16 (1): 43-54.

- 2005. The evolution of US GAAP: The political forces behind professional standards. The CPA Journal 75 (2): 19-29.

. 2013. The objectives of financial reporting: A historical survey and analysis. Accounting and Business Research 43 (4): 262-327. 


\section{TABLE 1}

Concepts Underlying Lease Accounting Choices in IFRS 16 Leases

\section{Lease}

accounting

issues

Recognition of an

asset

liability and a

\section{IFRS 16-specified accounting requirements}

- A lessee shall recognise a right-of-use asset and a lease liability (IASB 2016b, para. 22).

\section{Concepts/principles/reasons underlying} the specified accounting

- Asset/liability definitions (IASB 2016a, paras. BC24 and BC27).

- Relevant and faithful representation of the economics of the lease (IASB 2016a, para. BC19; 2013a, para. BC347).

- Comparability (IASB 2013a, para. BC355)

- Mitigates the problem of off-balance sheet financing created by operating leases (IASB 2016a, para. BC42).

\section{Short-term}

leases and low-

value leases

\section{Initial}

recognition and

measurement

date
- The lessee is allowed not to recognise a right-of-use asset and a lease liability for short-term leases and leases with low value underlying assets (IASB 2016b, para. 5).

- Initial recognition and measurement at the commencement date of the lease (IASB 2016b, paras. 22, 23 and 26).

- Cost constraint (IASB 2016a, paras. BC87-BC89, BC98-BC99).

- Consistency with the lessee accounting model (IASB 2016a, para. BC142).

- Will not result in the recognition of a gain or loss on the initial recognition of the right-of-use asset and the lease liability by the lessee (IASB 2016a, para. BC144).

- Consistency with the measurement date of other transactions such as the acquisition of an asset (IASB 2016a, para. BC144).

\begin{tabular}{llll}
\hline $\begin{array}{l}\text { Initial } \\
\text { measurement }\end{array}$ & $\begin{array}{l}\text { Right-of-use asset: the amount of the initial } \\
\text { measurement of the lease liability, plus any lease }\end{array}$ & $\begin{array}{l}\text { Decision-usefulness (IASB 2016a, para. BC145). } \\
\text { Consistent with the measurement of other similar } \\
\text { payment made at or before the commencement of the }\end{array}$ & $\begin{array}{l}\text { assets and liabilities (IASB 2016a, para. BC145). } \\
\text { lease, less any lease incentives received from the lessor, } \\
\text { plus any initial direct cost incurred by the lessee, plus } \\
\text { an estimate of dismantling and restoration cost (IASB }\end{array}$ \\
& $\begin{array}{l}\text { 2016b, para. 24). } \\
\text { Lease liability: present value of the lease payments } \\
\text { (IASB 2016b, para. 26). }\end{array}$ \\
\hline Initial direct cost & $\begin{array}{l}\text { Included as part of the carrying amount of the right-of- } \\
\text { use asset (IASB 2016b, para. 24). }\end{array}$ & $\begin{array}{l}\text { Consistency with the treatment of costs associated with } \\
\text { the acquisition of other non-financial assets (IASB } \\
\text { 2016a, para. BC149). }\end{array}$ \\
\hline
\end{tabular}




\begin{tabular}{lll}
\hline $\begin{array}{l}\text { Lease } \\
\text { options }\end{array}$ & term & $\begin{array}{l}\text { The lease term includes the option to extend the lease } \\
\text { if the lessee is reasonably certain to exercise the option }\end{array}$
\end{tabular}
(IASB 2016b, para. 18).

Variable lease

payments

- The lease payments include only those variable lease payments that are in-substance fixed, or depend on an index or rate (IASB 2016b, para. 27).

Residual value - Amount expected to be payable under the residual guarantee

\section{Subsequent} measurement value guarantee are included in the lease liability and the right-of-use asset (IASB 2016b, para. 27).

- Right-of-use asset: subsequently measured using a cost model, unless the fair value model or the revaluation

Re-assessment of the discount rate

Re-assessment of variable lease payments

Re-assessment of

the residual

value guarantee

Accounting for changes in lease payments

because of the reassessment model is chosen in conditions specified in paras. 34 and 35 (IASB 2016b, paras. 29, 34 and 35).

- The lease liability: subsequently measured using the amortised cost and re-measured to reflect any reassessment or lease modification, or revised insubstance fixed payments (IASB 2016b, para. 36)

- The discount rate shall be revised when there is a change in the lease term, or there is a change in the assessment of the option to purchase the underlying asset (IASB 2016b, para. 40).

- The lessee shall re-assess variable lease payments that are determined by reference to an index or rate only when there is a change in the cash flows resulting from a change in the reference index or rate (IASB 2016b, para. 42).

- Decision-usefulness (IASB 2016a, para. BC156).

- Constituents' feedback that the concept "reasonably certain" is consistent with IAS 17 and, hence, wellunderstood. This would facilitate consistent application (IASB 2016a, paras. BC156 and BC157).

- These payments are unavoidable, and hence meet the definition of a liability (IASB 2016a, paras. BC164 and BC165).

- These payments are unavoidable, and hence meet the definition of a liability (IASB 2016a, para. BC170).

- Consistency with the measurement of other nonfinancial assets and financial liabilities (IASB 2016a, paras. BC53 and BC182).

- Faithful representation: change in the economics of the lease because of a change in the lease term, or a change in the assessment of the option to purchase the underlying asset (IASB 2016a, para. BC194).

- Provides relevant information as it reflects current economic conditions (IASB 2016a, para. BC188 ).

- Cost constraint (IASB 2016a, paras. BC189 and BC190).

- Provides relevant information as it reflects current economic conditions (IASB 2016a, para. BC191).

The lessee shall re-assess the amount expected to be payable under the residual value guarantee (IASB 2016b, para. 42).

- The lessee shall recognise the amount of the remeasurement of the lease liability as an adjustment to the right-of-use asset (IASB 2016b, para. 39).

- A "change in the assessment of extension, termination or purchase options reflects the lessee's determination that it has acquired more or less of the right to use the underlying asset" (IASB 2016a, para. BC192).

- A change in the estimate of future lease payments is a 


\begin{tabular}{lr}
\hline variable & lease \\
payments & and \\
residual & value \\
guarantee &
\end{tabular}

guarantee

Lease expense
- The lessee shall present interest expense on the lease liability separately from the depreciation charge for the right-of-use asset (IASB 2016b, para. 49). revision of the initial cost of the right-of-use asset (IASB 2016a, para. BC192).

- Consistent with the accounting for a change in the estimated amount or timing of the outflow of resources associated with a change in the measurement of decommissioning, restoration, or similar liability (IASB 2016a, para. BC192).

- Decision-usefulness (IASB 2016a, para. BC209). 
EXHIBIT 1

Evolution of Lease Accounting Requirements for Short-Term and Low-Value Leases from the Discussion Paper to IFRS 16 Panel A: Accounting requirements for short-term and low-value leases in the Discussion Paper and Exposure Draft 2010 Due process IASB logic Accounting requirement

Accounting requirement Feedback by respondents

document

Discussion Paper

- Short-term leases may include material leases (IASB 2009, para. 2.19).

- Scope exclusions of short-term leases may encourage lease structuring (IASB 2009, para. 2.19).

- Arbitrary definition of short-term leases (IASB 2009, para. 2.19).
- Scope exclusions for immaterial items (IASB 2009, para. 2.14).

- The IASB did not reach preliminary views on shortterm leases (IASB 2009, para. 2.15).

- $\quad$ Short-term leases be excluded from the scope of the new lease accounting standard (IASB/FASB Staff 2009a, para. 26)

- Measurement exceptions The lessee is allowed to measure the right-of-use asset and the lease liability arising from short-term leases using undiscounted amount (IASB 2010d, para.

$\begin{array}{ll}\text { Scope exclusion would not provide } & \text { amo } \\ \text { a faithful representation of assets } & 64) \text {. }\end{array}$ and liabilities in the statement of financial position (IASB 2010a, para. BC43).

- Scope exclusion would create an artificial distinction between leases that are recognised and leases that are not (IASB 2010a, para. BC43).
- Discounting is not a significant driver of cost and time to implement the new lease accounting model (IASB/FASB Staff 2011, para. 76).

- The major cost of implementing the new model relates to "the costs of identifying, tracking, and recognising a significant number of short-term leases" (IASB/FASB Staff 2011, para. 76).

- Measurement exceptions do not provide significant cost relief to preparers (IASB/FASB Staff 2011, para. $76)$.

- Recognition exemption recommended for short-term leases (IASB/FASB Staff 2011, para. 78). 
EXHIBIT 1 (continued)

Panel B: Accounting requirements for short-term and low-value leases in Exposure Draft 2013 and IFRS 16

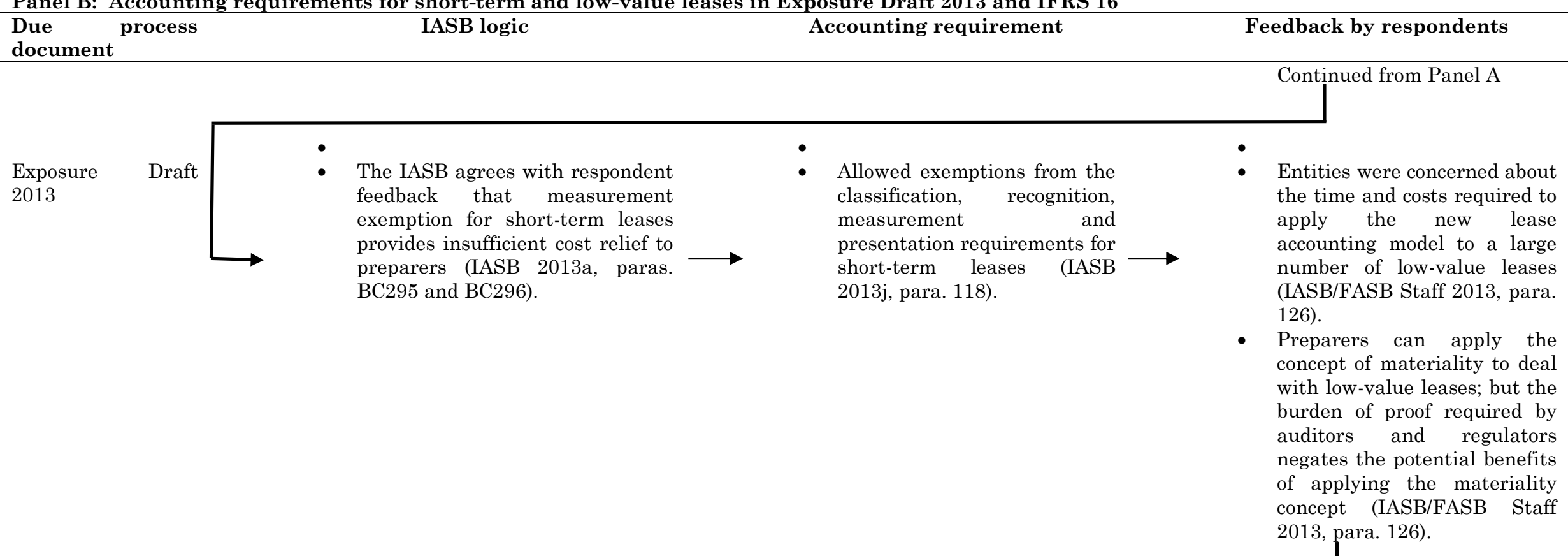

IFRS 16

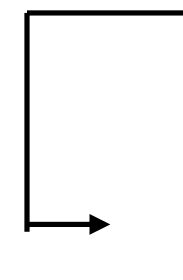

- The IASB concurs with the respondents' feedback that measurement exemption for short-term leases does not provide sufficient cost relief to lessees (IASB 2016a, paras. BC88-BC89).

- The IASB concurs with the feedback that exemption for short-term leases does not provide relief for leases of low-value assets (IASB 2016a, paras. BC90,
- Recognition exemptions for (a) short-term leases, and (b) leases of low-value assets (IASB 2016b, para. 5). 
BC98- BC99). 


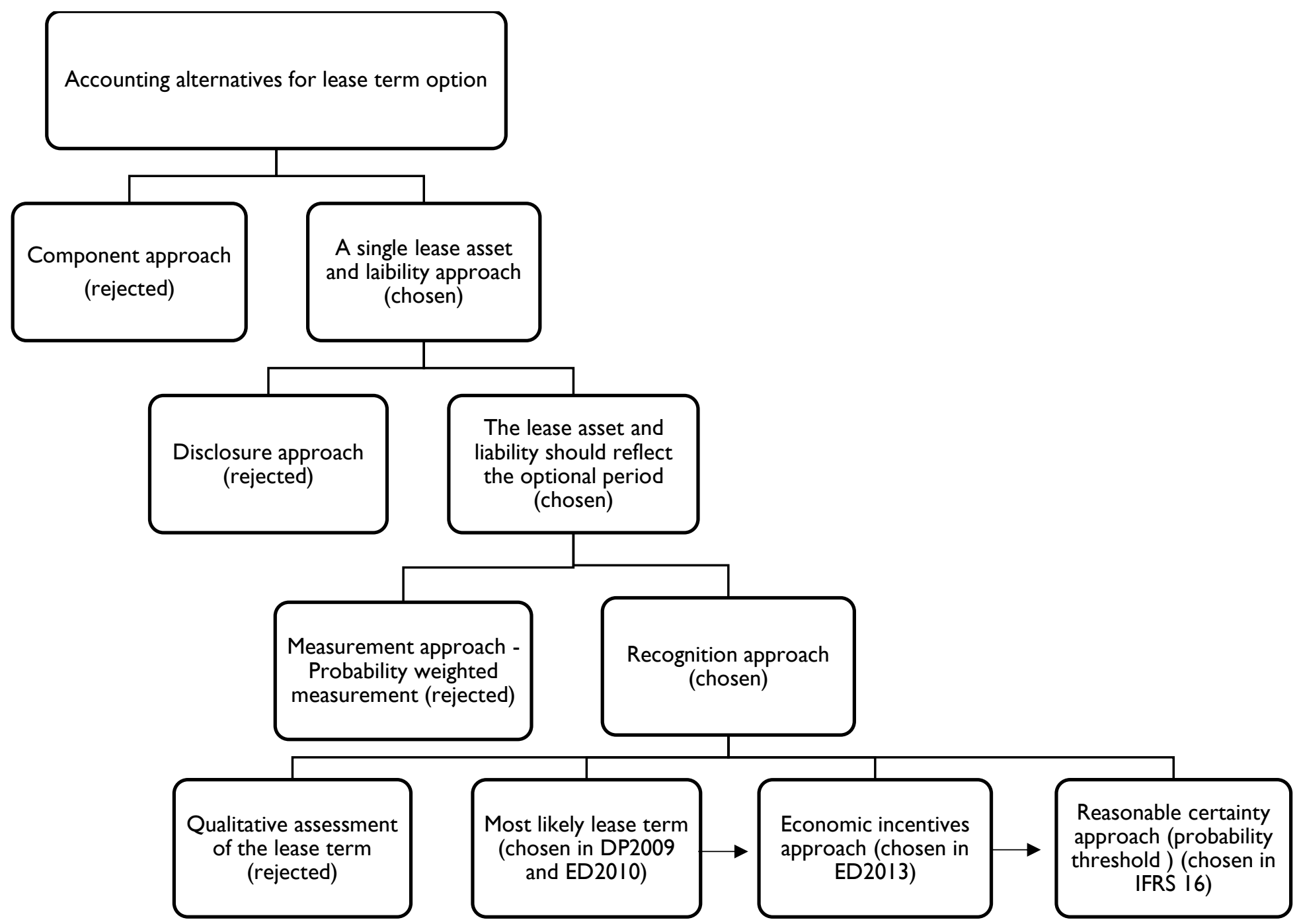

Figure 1. IASB's decision tree for accounting for the lease term option (IASB 2009, 2010a, 2013a, 2016a) 


\section{Table 3}

Determination of Requirements - The Case of the Lease Term Option ${ }^{1}$

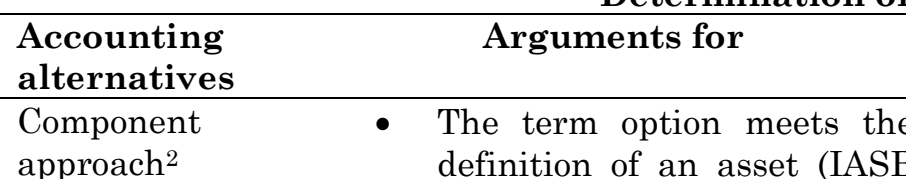
Arguments against

IASB's

IASB's rationale for the choice

(IASB 2016a,

para. BC153) 2009, paras. 3.31 and 6.8).

- The obligation to pay during the optional period is not a liability (IASB 2009, para. 6.8).

- Complex and difficult to implement (IASB 2009, 2010a, 2013a, 2016a).

- Ignores the interrelationship between the lease term and the exercise of the option (IASB 2009, 2010a, 2013a 2016a).
Disclosure

approach $^{3}$

(IASB 2016a,

para. BC153) 2013a, 2016a).
- Simple to apply (IASB 2010a

Ignores the existence of the option (IASB 2010a, 2013a, 2016a).

- Potentially misrepresents the assets and liabilities arising from the lease (IASB 2010a, 2013a, 2016a).
- Rejected

- Ignores the existence of the option (IASB 2013a, 2016a).

- Potentially

misrepresents the assets and liabilities arising from the lease (IASB 2013a, 2016a).

\begin{tabular}{|c|c|c|c|c|}
\hline $\begin{array}{l}\text { Measurement } \\
\text { approach - } \\
\text { Probability- } \\
\text { weighted } \\
\text { measurement } \\
\text { (IASB 2016a, } \\
\text { para. BC153) }\end{array}$ & $\begin{array}{l}\text { - Better reflects the existence } \\
\text { of the option than other } \\
\text { approaches (IASB 2009, } \\
\text { para. 6.14). } \\
\text { Mitigates the risk of off- } \\
\text { balance sheet liabilities } \\
\text { (IASB 2016a, para. BC155). }\end{array}$ & $\begin{array}{l}\text { - Reliable measurement of } \\
\text { probability is difficult (IASB } \\
\text { 2009, para. 6.15). } \\
\text { Lease payments during the } \\
\text { optional period do not meet } \\
\text { the definition of a liability } \\
\text { (IASB 2016a, para. BC154). }\end{array}$ & - $\quad$ Rejected & $\begin{array}{l}\text { Reliable measurement } \\
\text { of probability is difficult } \\
\text { (IASB 2009, para. 6.15). }\end{array}$ \\
\hline $\begin{array}{ll}\text { Recognition } & \\
\text { approach } & - \\
\text { Qualitative } \\
\text { assessment of }\end{array}$ & $\begin{array}{l}\text { - Simple to implement (IASB } \\
\text { 2009, para. 6.32). } \\
\text { - Avoids the bright-line test } \\
\text { associated with the }\end{array}$ & $\begin{array}{l}\text { - } \quad \text { Reduces comparability (IASB } \\
\text { 2009, para. 6.33). } \\
\text { - Need for additional guidance } \\
\text { (IASB 2009, para. 6.33). }\end{array}$ & - $\quad$ Rejected & $\begin{array}{l}\text { - } \quad \text { Reduces comparability } \\
\text { (IASB 2009, para. 6.36). }\end{array}$ \\
\hline
\end{tabular}




\begin{tabular}{|c|c|c|c|c|}
\hline $\begin{array}{l}\text { Accounting } \\
\text { alternatives }\end{array}$ & Arguments for & Arguments against & $\begin{array}{c}\text { IASB's } \\
\text { determination }\end{array}$ & $\begin{array}{r}\text { IASB's rationale for } \\
\text { the choice }\end{array}$ \\
\hline $\begin{array}{l}\text { the lease term } \\
\text { (IASB } 2009 \text {, } \\
\text { para. } 6.24(\mathrm{~b}) \text { ) }\end{array}$ & $\begin{array}{l}\text { probability threshold method } \\
\text { (IASB 2009, para. 6.32). }\end{array}$ & & & \\
\hline \begin{tabular}{l}
\multicolumn{2}{l}{ Recognition } \\
approach \\
Most $\quad$ likely \\
lease $\quad$ term $^{6}$ \\
(IASB 2009 , \\
para. $6.24(\mathrm{c})$ )
\end{tabular} & $\begin{array}{l}\text { - } \text { Simple to apply (IASB 2010a, } \\
\text { para. BC115). } \\
\text { Eliminates the need to } \\
\text { differentiate between options } \\
\text { to renew and option to } \\
\text { terminate a lease (IASB } \\
\text { 2010a, para. BC115). } \\
\text { Reflects entity-specific } \\
\text { factors (IASB 2010a, para. } \\
\text { BC115). } \\
\text { Reflects expected outcome } \\
\text { (IASB 2010a, para. BC115). } \\
\text { Avoids the measurement } \\
\text { reliability problem associated } \\
\text { with other methods (IASB } \\
\text { 2010a, para. BC115). } \\
\text { A practical solution to the } \\
\text { accounting problem for the } \\
\text { lease term option (IASB } \\
\text { 2010a, para. BC117). }\end{array}$ & $\begin{array}{l}\text { - Results in the recognition of } \\
\text { a lease liability that does not } \\
\text { meet the definition of a } \\
\text { liability (IASB 2010a, para. } \\
\text { BC116). } \\
\text { Fails to distinguish between, } \\
\text { for example, a non- } \\
\text { cancellable 10-year lease and } \\
\text { a non-cancellable 5-year } \\
\text { lease with an option to } \\
\text { extend for five more years } \\
\text { (IASB 2010a, para. BC116). }\end{array}$ & - Rejected & 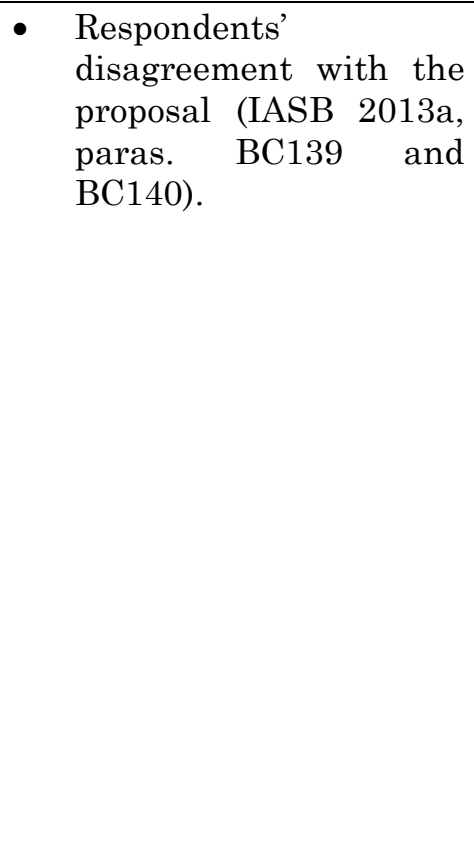 \\
\hline $\begin{array}{l}\text { Recognition } \\
\text { approach } \\
\text { Economic } \\
\text { incentive } \\
\text { method }^{7} \quad \text { (IASB } \\
2016 a, \quad \text { para. } \\
\text { BC153) }\end{array}$ & 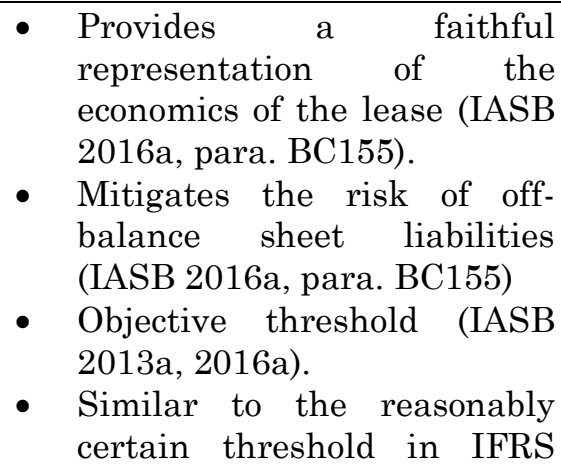 & $\begin{array}{l}\text { - Lease payments during the } \\
\text { optional period do not meet } \\
\text { the definition of a liability } \\
\text { (IASB 2016a, para. BC154). } \\
\text { Fails to distinguish between, } \\
\text { for example, a non- } \\
\text { cancellable 10-year lease and } \\
\text { a non-cancellable 5-year } \\
\text { lease with an option to } \\
\text { extend for five more years } \\
\text { (IASB 2009, para. 6.21). }\end{array}$ & - Rejected & 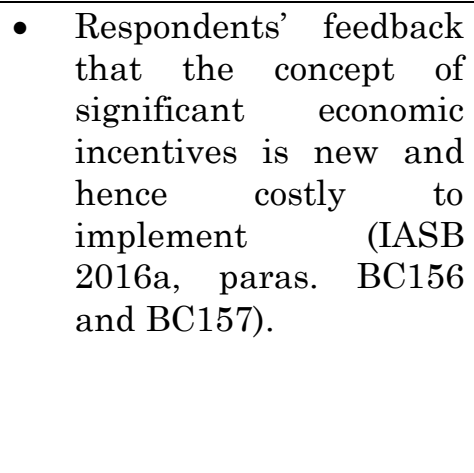 \\
\hline
\end{tabular}




\begin{tabular}{|c|c|c|c|c|}
\hline $\begin{array}{l}\text { Accounting } \\
\text { alternatives }\end{array}$ & Arguments for & Arguments against & $\begin{array}{c}\text { IASB's } \\
\text { determination }\end{array}$ & $\begin{array}{r}\text { IASB's rationale for } \\
\text { the choice }\end{array}$ \\
\hline & (IASB 2013a, 2016a). & $\begin{array}{l}\text { - New concept and hence, } \\
\text { costly to implement (IASB } \\
\text { 2016a, para. BC156). }\end{array}$ & & \\
\hline $\begin{array}{l}\text { Recognition } \\
\text { approach } \\
\text { Probability } \\
\text { threshold } \\
\text { method }^{8} \text { (IASB } \\
2016 a \text {, para. } \\
\text { BC153) }\end{array}$ & 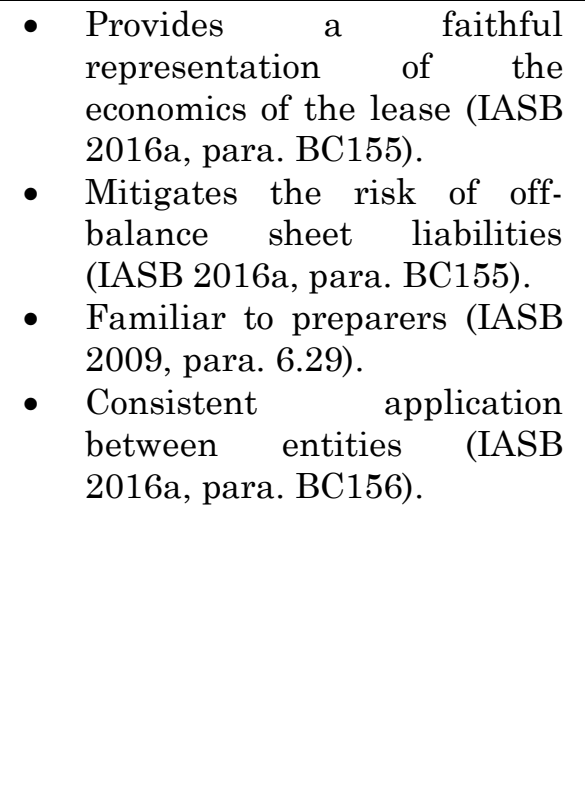 & $\begin{array}{l}\text { - Lease payments during the } \\
\text { optional period do not meet } \\
\text { the definition of a liability } \\
\text { (IASB 2016a, para. BC154). } \\
\text { Fails to distinguish between, } \\
\text { for example, a non- } \\
\text { cancellable 10-year lease and } \\
\text { a non-cancellable 5-year } \\
\text { lease with an option to } \\
\text { extend for five more years } \\
\text { (IASB 2009, para. 6.21). } \\
\text { No conceptually correct } \\
\text { probability threshold (IASB } \\
\text { 2009, para. 6.30). } \\
\text { Bright-line test (IASB 2009, } \\
\text { paras. 6.27 and 6.30). } \\
\text { Creates structuring } \\
\text { opportunities (IASB 2010a, } \\
\text { para. BC117). }\end{array}$ & 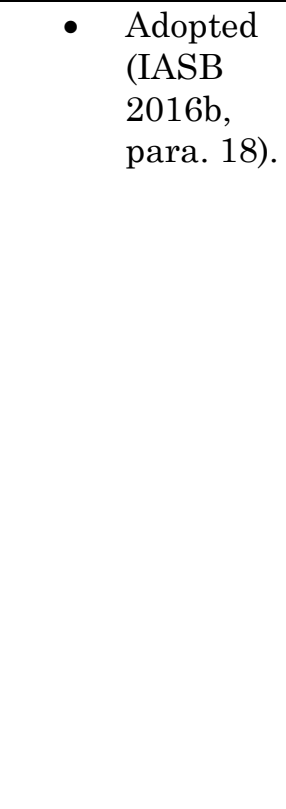 & $\begin{array}{l}\text { - Provides decision-useful } \\
\text { information (IASB } \\
\text { 2016b, para. BC156). } \\
\text { Respondents' feedback } \\
\text { that the probability } \\
\text { threshold of 'reasonably } \\
\text { certain' is consistent } \\
\text { with IAS 17, and hence } \\
\text { is well-understood } \\
\text { (IASB 2016a, paras. } \\
\text { BC156 and BC157). It } \\
\text { would, thus, allow } \\
\text { consistent application } \\
\text { across entities. }\end{array}$ \\
\hline \multicolumn{5}{|c|}{ 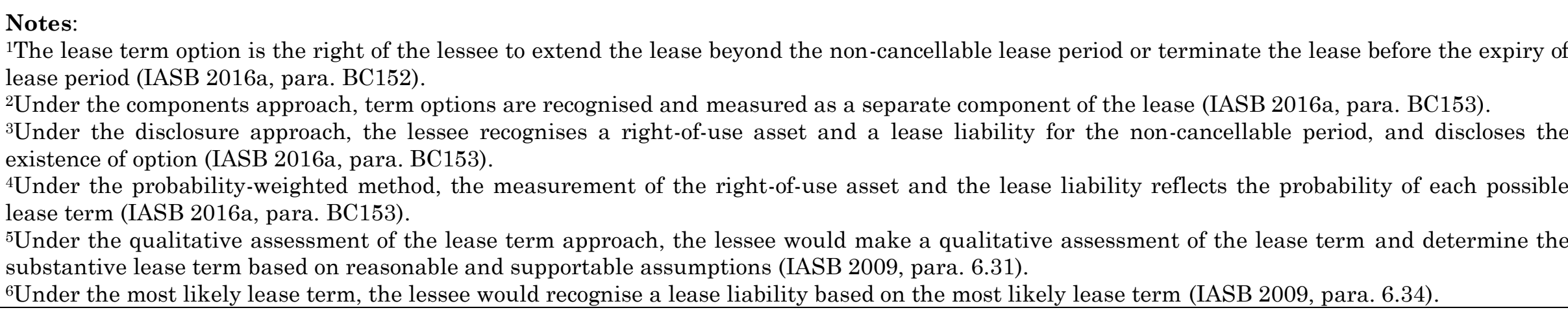 } \\
\hline
\end{tabular}


7Under the economic incentive method, the lessee includes the optional period in the lease term if the lessee has an economic incentive to exercise the option (IASB 2016a, para. BC153).

8Under the probability threshold method, the lessee includes the optional period in the lease term if the probability of exercising the option meets a certain threshold (IASB 2016a, para. BC153). IFRS 16 adopts this method using 'reasonably certain' as the probability threshold (IASB 2016b, para. 18). 